\title{
COMPORTAMENTO DE CLONES DE Eucalyptus grandis W. HILL EX. MAIDEN EM SOLO PODZÓLICO VERMELHO ESCURO E AREIA QUARTZOSA ÁLICA EM LENÇÓIS PAULISTA, SP
}

\author{
GILMAR BERTOLOTI \\ ENGㅇ FLORESTAL
}

Orientador: Prof. Dr. PAULO Y. KAGEYAMA

Dissertação apresentada à Escola Superior de Agricultura "Luiz de Queiroz", da Universidade de São Paulo, para obtenção do título de Mestre em Engenharia Florestal.

PIRACICABA

Estado de São Paulo - Brasil

Dezembro - 1986 


\author{
Aos meus irmãos: TATÃo, GILSON, SILVINHA \\ E SILEI MINHA CONSIDERAÇÃO
}

Aos meus pais: Dna. LOLA e SÍlVIo
Agradeço

A MIRIAM

Dedico. 
- Ao Prof. PAULOY. KAGEYAMA pela orientação que nos ofereceu desde o planejamento do trabalho atē as anālises e apresentação do texto final.

- A equipe técnica da DURATEX FLORESTAL S.A. pelo apoịo material e humano na instalação e manutenção dos ensaios, coleta de dados e análise dos resultados.

- Aos Engos DEUSELIS J. FIRME e WEBER A. DO AMARAL NEVES da FLORIN - Florestamento Integrado S.A. pelo auxilio nas anālises técnicas.

- Ao IPEF - Instituto de Pesquisas e Estudos Florestais pelo auxilio financeiro que nos ofereceu no período de Janeiro de 1980 a Junho de 1981.

- A Sra. ISABEL CRISTINA ANDREUCETTI e à Sra. MARIA MARTA WEBER DO NASCIMENTO pela dedicação no trabalho de datilografia.

- Ao Prof. Antonio Natal Gonçalves e ao Engo Ftal Antonio Fernando Elias, pelas traduções em Inglès. 
iii.

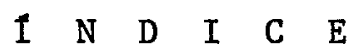

Pägina

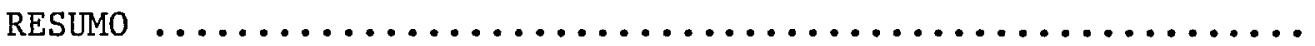
vii

SUMMARY

viii

1. INTRODUÇÃO

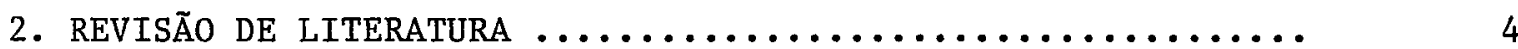

2.1 - Características físicas e químicas dos solos destinados ao reflorestamento $\ldots \ldots \ldots \ldots \ldots \ldots \ldots \ldots \ldots \ldots$

2.1 .1 - Os solos sob cerrado ................. 5

2.1 .2 - o conceito de sítio $\ldots \ldots \ldots \ldots \ldots \ldots \ldots \ldots \ldots$

2.1.3 - A extração dos nutrientes pelo Eucalyptus ... 10

2.2 - As interações genötipo $\mathrm{x}$ ambiente $\ldots \ldots \ldots \ldots \ldots \ldots \ldots \ldots$

2.2 .1 - Conceitos gerais ................... 11

2.2.2 - Competição intergenotípica ............. 15

2.2.3 - Clones e fertilidade do solo ............. 20

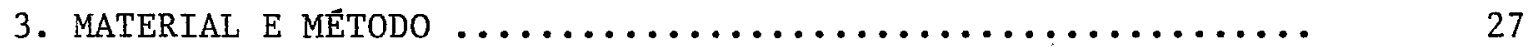

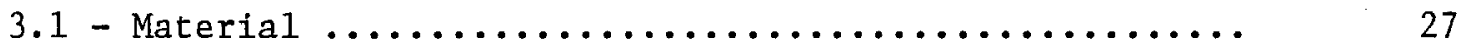

3.1 .1 - Localização dos ensaios ............... 27

3.1 .2 - Características climáticas ............. 27

3.1 .3 - Material genético empregado ............. 28

3.1 .4 - Caracterização do solo ............... 29

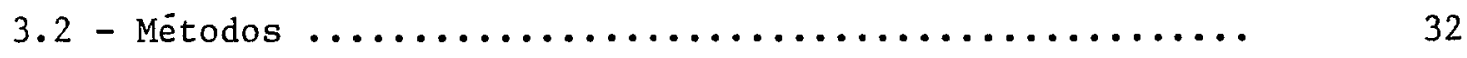

3.2.1 - Präticas Silviculturais Adotadas ......... 32 
iv.

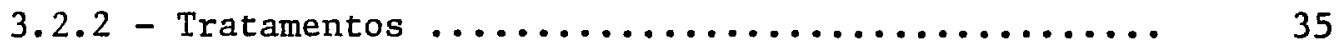

3.2 .3 - Delineamento Estatístico .............. 36

3.2 .4 - Esquema Estatistico de Anälise ........... 36

3.2 .5 - Ãrea do Ensaio ................... 37

3.2 .6 - Coleta de Material Vegetativo para Anālise .... 38

3.2 .7 - Coleta de dados no campo ............... 39

4. RESUltados E DiscusSÃo ........................ 40

4.1 - Considerações sobre o Melhoramento Genëtico ......... 40

4.1 .1 - Sobrevivēncia $\ldots \ldots \ldots \ldots \ldots \ldots \ldots \ldots \ldots \ldots \ldots . \ldots \ldots$

4.1 .2 - Altura $\ldots \ldots \ldots \ldots \ldots \ldots \ldots \ldots \ldots \ldots \ldots \ldots \ldots \ldots, 42$

4.1 .3 - Diāmetro à altura do Peito (DAP) .......... 48

4.1 .4 - Volume $\ldots \ldots \ldots \ldots \ldots \ldots \ldots \ldots \ldots \ldots \ldots \ldots \ldots \ldots \ldots \ldots$

4.2 - Considerações sobre o aspecto nutricional .......... 59

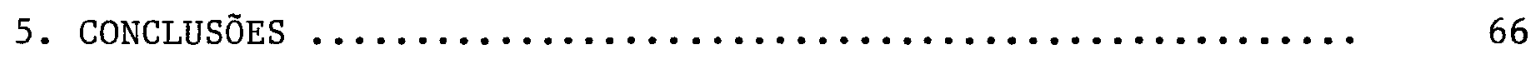

6. LiteratURA CITADA .......................... 68

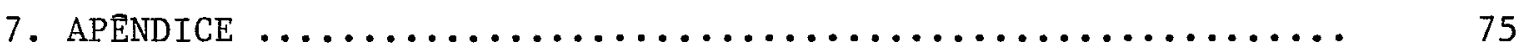




\section{CONPORTANTENTO DE CIONES DE Eucalyptus : grandis W.HIIL EX. MAIDEN EM SOIO PODZÓIICO VERNEIHO ESCURO E AREIA QUARTZÓSA: ÁLICA EMI IENCOIS PAULISTA-SP.}

Autor: GILMAR BERTOLOTI

Orientador: Prof. Dr. PAULO YOSHIO KAGEYAMA

RESUMO

0 presente estudo foi desenvolvido em dois solos com diferentes fertilidades, caracterizados como Podzölico Vermelho Escuro ( P VE ) e Areia Quartzosa Alica (AQ), localizados na região de Lençois Pau lista - SP em āreas da DURATEX FLORESTAL S.A. Os dois locais apresentam semelhanças quanto às características climäticas.

o estudo objetivou: a) observar a variação genética en tre clones de E. grandis propagados por estaquia; b) verificar a intera ção clones $\mathrm{x}$ solos com diferentes fertilidades; c) comparar o comportamen to silvicultural de clones e material propagado por sementes com diferentes graus de melhoria genética; d) avaliar o efelto da competição entre ärvores em parcelas monoclonais e misturas de clones.

Foram testados 16 tratamentos, distribuidos em blocos ao acaso com trēs repetições, em parcelas de 36 plantas e espaçamento de $3,0 \mathrm{~m} \times 3,0 \mathrm{~m}$.

Os tratamentos estudados foram:

- Parcelas monoclonais de oito clones constituídos por plantas propagadas por estaquia (8 tratamentos). 
vi.

- Parcelas multiclonais constituidas por plantas dos oito clones, propagados por estaquia. Os oito clones foram distribuídos ao acaso na parcela (3 tratamentos).

- Parcelas constituídas por plantas produzidas por' sementes de pomar clonal propagado por enxertia (2 tratamentos).

- Parcelas constituídas por plantas produzidas por sementes das oito ärvores selecionadas (matrizes), de cujas touças retiraram-se as estacas (2 tratamentos).

- Parcelas constituídas por plantas originärias de sementes de E. grandis, ex Africa do Su1, e colhidas em povoamentos comer ciais da DURATEX FLORESTAL S.A. em Lençōis Paulista - SP.

Os resultados e conclusões da avaliação aos 24 meses foram:

a) a produtividade média no PVE $\left(126,29 \mathrm{~m}^{3}\right.$ sólidos / ha), foi $57,32 \mathrm{~m}^{3} /$ ha superior (83\%) à media de produtividade da $\mathrm{AQ}(68,97$ $\left.\mathrm{m}^{3} / \mathrm{ha}\right)$;

b) os materiais propagados via semente apresentaram melhores resultados para pomar clonal, vindo a seguir as sementes de ma trizes e por ültimo as sementes comerciais. O material propagado por esta quia não correspondeu à expectativa teórica;

c) As parcelas multiclonais apresentaram desenvolvimen 
vii.

to superior às parcelas monoclonais, principalmente no PVE, onde a su perioridade foi de $8,1 \%$ em volume;

d) houve variação genética entre clones nos dois solos testados;

e) a interação dos dois materiais genéticos com os dois solos mostrou-se pouco expressiva, com comportamento semelhante dos mes mos nos dois solos;

f) as estimativas de ganhos genéticos reais foram inferiores às teoricamente esperadas;

g) os materiais genēticos mostraram variações nas concentrações de nutrientes em suas folhas. 
viii.

CLONAI PERFORMANCE OF Eucalyptus grandis W. HIII EX. MAIDEN IN DARK RED PODZOIIC AND AIUTIMOUS QUARTZOUS SAID SOII IN IENÇOIS PAUIISTA SP

Author: GILMAR BERTOLOTI

Advisor: PAULO YOSHIO KAGEYAMA

\section{SUMMARY}

The objectives of this work were:

a) to observe the genetic variation among clones of Eucalyptus grandis ' produced by cutting;

b) to verify the interaction of clones $x$ soils with different fertility levels;

c) to compare the silvicultural performance of clones produced by cutting and trees produced from seeds with different genetic improvement levels; and

d) to evaluate the compettional effect among trees in monoclonal and multi clonal plots. 
ix.

The trials were established in two soils with diffe rent fertility levels and characterized as dark red podzolic (PVE) and ' aluminous quartzous sand ( $A Q)$ under similar climatic conditions in the re gion of Lençōis Paulista - SP.

The trials were set up in a randomized block design with 16 trataments and three replications utilizing 36 trees in spacings of $3,0 \times 3,0 \mathrm{~m}$ plots. The treatments were as floows:

1. Eight treatments with different monoclonal plots consisting of trees propagated by cutting;

2. Three treatments with multiclonal plots. Each plot consisted of a misture of the 8 clones propagated by cutting;

3. Two treatments with plots consisting of trees propagated by seeds from a clonal seed orchad established by grafting;

4. Two treatments with plots consisting of trees propagated by seeds from 8 selected trees that gave origin to the 8 clones;

5. One treatment with plots consisting of trees propagated by seeds collec ted from commercial stands of E grandis (ex South Africa) in Lençöis Paulista - SP.

The analysis of the results from evaluations made at 24 months of age allowed the following conclusions: 
a) The mean production for the PVE soil $\left(126,29 \mathrm{~m}^{3} / \mathrm{ha}\right)$ was $83 \%\left(57,32 \mathrm{~m}^{3} /\right.$ ha) higher than that for the QA soil $\left(68,97 \mathrm{~m}^{3} / \mathrm{ha}\right)$.

b) Trees propagated by seeds showed higher productions than those propaga ted by cutting. In this case, the highest production was obtained by trees propagated by seeds from the clonal seed orchard, followed by those from selected trees and the last, those from commercial stands;

c) The treatments with multiclonal plots showed a higher production than those with monoclonal plots. In the PVE soil, the production in volume for the multiclonal plots was $8,1 \%$ higher than that for the monoclonal plots;

d) Genetic variations among clones were detected in the two soils tested;

e) The interaction of the two types of genetic material (clones and seeds) with the two soils showed little expression with similar performance in both soils;

f) The estimates for the observed genetic gains were lower to those theote tically expected;

g) The genetic material utilized showed variation in the leaf mineral nutrient content. 
1. INTRODUÇÃO

A diversidade das condições edafo-climāticas, presentes nas āreas destinadas ao plantio de espëcies de räpido crescimento, tem contribuido de maneira expressiva, para que os programas de melhoramento genético florestal se integrem cada vez mais às técnicas de manejo, visan do à melhoria de algumas características fenotípicas e genotípicas das ār vores: volume, forma, resistência às pragas e doenças, qualidade tecnológica da madeira, rebrota, dentre outras.

o emprego cada vez maior de técnicas de zoneamento e classificação de solos objetivando conhecer com mais detalhes suas pro priedades, bem como a seleção e propagação de clones de espécies flores tais de Eucalyptus e Pinus com altas produtividades, forçaram o desenvolvimento de pesquisas no sentido de gerar informações mais precisas sobre . o processo da interação genótipo $x$ ambiente.

o excessivo aumento nos custos de fertilizantes quími- 
micos, ocorrido no Brasil nos ültimos anos, também tem contribuído para o direcionamento dos programas de melhoramento genētico em busca de mate riais com alta eficiēncia biológica.

Em virtude da utilização, em larga escala, da clonagem de ärvores fenotipicamente superiores, formando extensos maciços flores tais, muitas vezes com base genética restrita, surgiu a necessidade de se avaliar os possíveis riscos a que estão submetidos tais plantios, principalmente quanto ao ataque de pragas e doenças.

Este fato abriu também a possibilidade de se incentivar pesquisas que quantifiquem os efeitos da implantação de povoamentos ' multiciclonais sem o comprometimento da produtividade, aumentando a varia bilidade genética e diminuindo a vulnerabilidade de tais plantios.

Conclui-se, portanto, que um melhor conhecimento das interações genōtipo $\mathrm{x}$ ambiente em espëcies florestais deverä ser por muitos anos o ponto de convergência dos programas de pesquisa sobre melhoramento e manejo florestal.

Em vista disso, desenvolveu-se o presente trabalho com os seguintes objetivos:

a) observar a variação genëtica entre clones de Euca lyptus grandis HILL - ex MAIDEN propagados por estaquia; 
3.

b) verificar a interação clones $x$ solos, com.diferen tes niveis de fertilidades;

c) comparar o comportamento silvicultural de ärvores ' oriundas de clones e material propagado por sementes, com diferentes graus de melhoria genética;

d) avaliar o efeito da competição entre ärvores em par celas monoclonais e misturas de clones. 
4.

2. REVISÃO DE LITERATURA

\section{1 - Características Físicas e Químicas dos Solos Destinados ao Reflo restamento}

0 sucesso a ser esperado nos empreendimentos que en volvam a participação do solo está subordinada à habilidade de interpreta ção daquilo que o mesmo pode oferecer, para satisfação dos propósitos almejados. Para um solo tornar-se conhecido a ponto de se poder interpretälo para uso agrícola ou florestal, deve ser antes identificado e classifi cado. Sō depois dessa etapa è que poder-se-ā exercer convenientemente o uso, manejo e conservação de uma terra, sem sacrifício dos méritos das atividades aplicadás, (Ranzani e França, 1968 citados por BARRoS, 1980). A vantagem primordial em se classificar, analisar e estudar um solo é a pos sibilidade de planejamento imediato ou futuro que estas pesquisas possibi 1itam (CARMEAN - 1979). Os autores afirmam ainda que a maioria dos estu dos solo-sítios existentes explicam de 65 a $85 \%$ das variaçōes em altura ' de ärvores (Índice de sítios) observadas em campo. 
A produtividade determinada por parämetros do so lo estā sendo usada como base para taxar solos florestais. Muitos destes estudos tēm abordado solo e sítio, com o objetivo de determinar relaçōes, que possam ser aplicadas em procedimentos no campo, ou seja, o objetivo tem sido prático, mais precisamente, o de determinar as propriedades do solo que governam a habilidade em produzir ärvores (GESSEL - 1982). 0 desenvolvimento de tëcnicas para determinar a produtividade florestal, usan do parāmetros do solo, tem precedido o manejo florestal. Igualmente impor tante, na previsão de produtividades futuras, è a habilidade dos reflores tadores em reconhecer e classificar sitios em unidades florestais para es pecificar tipos de manejo.

Segundo McCool e Powers (1976), citados por BALLONI (1979), o termo fertilidade do solo generaliza a capacidade que o mesmo tem de satisfazer as necessidades nutricionais das plantas, sob condições climāticas e genēticas controladas. A fertilidade não è um parāmetro estätico; depende da estabilidade de ecossistema, pondendo flutuar próximo a um estado de equilíbrio dinâmico ou ser totalmente alterada apōs um distürbio. Os mesmos autores afirmam que präticas de manejo e exploração' florestal causam alterações bruscas no ciclo de nutrientes da floresta, refletindo negativamente na fertidiade dos solos.

\section{1 .1 - Os Solos sob "cerrado"}

A área sob vegetação de cerrado ocupa 1,8 milhões 
de $\mathrm{Km}^{2}$, ou cerca de $20 \%$ do Brasil, estendendo-se principalmente pela região Centro-0este e atingindo ainda parte da região Norte, Nordeste e Sudeste (EMBRAPA - 1978).

De acordo com SANCHES et alii (1976), as principais unidades de solos que ocorreram na região dos "cerrados" são os Latosso los, ocupando cerca de $56 \%$ do total, seguindo-se cerca de $20 \%$ de Areias ' Quartzosas, $10 \%$ de Lateritas Hidromórficas, 9\% de Litossolos e menores por centagens de Podzólicos.

Ranzani (1962), citado por LOPES (1983), concluiu, que os solos de cerrado em sua maioria são profundos, sem barreiras físicas para o desenvolvimento normal das raízes das plantas cultivadas, somando-se ainda caracteristicas de boa estrutura e superfícies de declive suave. Quanto à textura, o autor acredita ser esta a caracteristica física mais importante destes solos, em razão da sua estreita relação com "f́i xação de fösforo" , capacidade de retenção de ägua, capacidade de troca ' cationica e outras.

o autor concluiu que hä um aumento na capacidade de troca catiōnica, CTC, à medida que aumenta o teor de argila. Sobre a capacidade de retenção de ägua, acredita-se, com base em diversos traba 1hos desenvolvidos nestes solos, estar evidenciada a sua baixa capacidade de retenção e o fato desta característica relacionar-se intimamente com 
as características texturais e teores de matéria orgānica, apesar das dis crepāncias entre as metodologias usadas para avaliação do parāmetro citado.

LOPES (1983) observou que solos arenosos apresen tam muito menos "ägua disponível", do que outros grupos texturais (barren to, argiloso e muito argiloso). Observou-se, também, que solos com 35 a $60 \%$ de argila apresentaram uma tendēncia de terem as quantidades máximas de "água disponível". A maioria dos trabalhos desenvolvidos em solos sob "cerrado" analisados por LOPES (1983), apesar das divergēncias no estabelecimento de critërios definidos para relacionar classes texturais e porcentagem de ägua disponível, permite chegar à conclusão de que todos são concordantes, sob o aspecto de que os solos arenosos (menos que $18 \%$ de ar gila) são, definitivamente, os que apresentam este parämetro em menor por centagem.

Outra consideração importante é a de que mesmo os solos barrentos, argilosos e muito argilosos não apresentam altos valores para o nível de ágúa disponível e deverão, caso o sistema radicular das plantas não encontre condições para se aprofundar nestes solos, apresen tar tambēm sërios problemas de dëficit hídrico, dependendo da intensidade de "veranicos".

\section{1 .2 - o conceito de sitio}


Segundo SCHLATTER (1983), diferentes espëcies vegetais, apresentam diferentes exigēncias em termos de sítio e principalmente em termos nutricionais. Com a constāncia de uma espëcie vegetal, o sitio define-se então como a combinação dos fatores de clima e solo.

GESSEL (1982) considera o solo como o fator mais impor tante na equação da produtividade florestal e o julga extremamente sensível aos impactos das präticas florestais. As mudanças no seu sistema podem ter efeitos imediatos ou ao longo dos anos, em termos benéficos ou em detrimento da produtividade florestal. Além disso, os solos diferem ampla mente em suas habilidades para absorver mudanças.

GESSEL (1982) comenta que boa estrutura, baixa densidade e alta porosidade, geralmente identificam sitios produtivos. Estruturas ' barrentas e subsolos firmes não representam meios favoräveis ao desenvo1vimento de raízes das espécies florestais e associações com microorganismos. A perda da superfície de solos por erosão, ou mudanças na estrutura, por atividades florestais podem ser prejudiciais à produtividade, todavia, a relação entre produtividade e mudanças na estrutura e porosidade ' do solo não estā bem documentada.

CARMEAN (1979), tambëm identificou alguns parāmetros do solo, os quais podem ser usados para avaliação do sítio, devido à sua intima relação com fatores de crescimento a saber: capacidade de absorção de 
ägua, elementos minerais, aeração, profundidade total do solo disponível para as raizes das ärvores, camadas especificas do solo, especialmente a profundidade do horizonte $A_{1}$, pelo seu conteüdo de matēria orgänica.

BARROS (1980) considera que a topografia se rela ciona estreitamente com microclimas, desenvolvimento de solos, regime de nutrição, regimes de umidade e, consequentemente, é boa indicadora da qua lidade do sitio.

$$
\text { QUILKIN (1973), citado por BARROS (1980), julga ' }
$$

que estratificação de sítios com base nas características topogräficas po dem melhorar a precisão para estimar a qualidade do sitio. Porēm RALSTON (1980), considera que detalhes excessivos em classificações topogräficas, podem levar a erros. 0 mesmo autor, confirma que no Brasil, a grande quan tidade de declives afetou negativamente o rendimento de $\underline{E}$ alba, que cres cia em um latossolo e foi responsável por $88 \%$ das variações de altura.

Sobre os fatores edäficos propriamente ditos, o mes mo autor julga que as variações no crescimento das ärvores dentro de uma mesma classe topogräfica, frequentemente se associam à disponibilidade de àgua, aeração do solo e disponibilidade de nutrientes. Logo, as propriedades do solo, que afetam estes fatores na zona de crescimento de raízes, relacionam-se com a qualidade do sítio. 


\subsection{3 - A extração de nutrientes pelo EUCALYPTUS}

GESSEL (1982), afirma que não existe quantificação adequada da influēncia das propriedades físicas e químicas na produtivida de dos sistemas florestais. Cita o exemplo, na ärea de anālises quimicas' de subsolo e suprimento nutricional, onde julga "estarmos pobremente equi pados para que dados de pesquisas laboratoriais possam generalizar as necessidades e performance dos sistemas florestais".

BALLONI (1978), afirma que uma das razões das difí culdades encontradas na verificação de limites entre anālises químicas e fertilidade dos solos, estā na metodologia empregada na coleta e anālise dos solos florestais, a qual normalmente è a mesma utilizada para culturas agrícolas, não sendo observadas as diferenças de extensão e profundidade dos sistemas radiculares das ärvores, os quais permitem a exploração de um volume de solo bastante variável e superior ao das culturas agrícolas.

Plantas do gēnero Eucalyptus retiram do solo grande quantidade de elementos minerais. Esta extração pode variar de acordo com o tipo de solo, densidade do povoamento e tipo de exploração. Depen dendo da intensidade e do material explorado(ramos, folhas, cascas, etc), pode haver um déficit nutricional às rotações posteriores. Caso não haja uma complementação por meio de práticas de adubação (HAAG et alii, 1983). 
BELLOTE et alii (1980) estudaram as quantidades de nutrientes exportados pelo caule de E. grandis em diversas idades. Para os macronutrientes observaram-se altas porcentagens de exportação pela cultụ ra, sendo o magnésio o mais exportado do total extraído pelas plantas vin do a seguir, em ordem decrescente: $\mathrm{P}>\mathrm{Ca}>\mathrm{K}:>\mathrm{S}>\mathrm{N}$. Para todos os macronutrientes o cälcio foi o mais exportado em quantidade, seguindo em or dem decrescente $\mathrm{N}>\mathrm{K}>\mathrm{S}>\mathrm{Mg}>\mathrm{P}$.

\section{2 - As interações Genötipo x Ambiente}

\subsection{1 - Conceitos Gerais}

Considerando que o fenótipo é resultado de influēn cias ambientais e genéticas, Robinson e Kockerman (1965) enfatizam que a estimativa dos parāmetros genéticos devem ser calculados independente dos efeitos ambientais, condição que se satisfaz somente quando não existem ' interações com o ambiente. Essa dificuldade è contornada testando genōtipos em diferentes locais, de tal forma que se possa isolar a variāncia ge nética da variāncia decorrente das interações entre os genótipos e ambien tes.

Thor e Rink (1976) destacam que a maioria das esti mativas de variāncia genētica em espēcies florestais è baseada em experimentos em um só ambiente, podendo estar superestimados pela presença de interação genōtipo $\mathrm{x}$ ambiente. 
Ainda que aparentemente o ambiente não mude por in fluências externas, os genötipos possuem tendēncia para modificar o ambiente em que vegetam. Assim, conforme as ärvores crescem, o sombreamento ' interno da parcela vai se incrementando e ocorrem mudanças na temperatura do ar e do solo, na umidade relativa, na disponibilidade de ägua e de nutrientes, que afetam o desenvolvimento e as características das plantas ( PATIÑO-VALERA, 1986).

Dependendo dos objetivos do melhoramento, a sele ção poderä favorecer genötipos amplamente adaptados ou genótipos que respondem a ambientes particulares (NAMKOOG et alii, 1980).

Por sua vez QUIJADA (1980) define a interação genō tipo $\mathrm{x}$ ambiente como sendo a falta de uniformidade na resposta de dois ou mais grupos de plantas em dois ou mais ambientes. Um grupo pode demons trar o melhor crescimento em um ambiente, mas ser péssimo em outro.

VENCOVSKY (1978) enfatiza que os efeitos das interaçōes entre genótipo $\mathrm{x}$ ambiente não são transmissíveis aos descendentes por cruzamentos, ou seja, por polinização livre ou controlada.

Os possiveis modos de interação foram esquematicamente representados por FONSECA (1979) e apresentados na Tabela 1. 
TABELA 1. Possiveis modos de interação genōtipo $x$ ambiente.

\begin{tabular}{|c|c|c|c|c|c|}
\hline \multirow{2}{*}{\multicolumn{2}{|c|}{ FONTES DE VARIAÇÃO }} & \multicolumn{4}{|c|}{$S I T U A C \tilde{O} E S$} \\
\hline & & 1 & 2 & 3 & 4 \\
\hline GENÓTIPO & (G) & $* *$ & $\mathrm{n} \cdot \mathrm{s}$ & $* *$ & $* *$ \\
\hline AMBIENTE & (A) & n.s & $* *$ & ** & n.s \\
\hline INTERAÇĀO & (GXA) & n.s & n.s & $* *$ & $* *$ \\
\hline
\end{tabular}

n.s. = não significativo estatisticamente

** = significativo estatisticamente

FONTE: FONSECA (1979)

Observa-se que na situação 1 por exemplo, existe' somente a diferença entre genótipos. Jä no caso 2, a escolha de um determinado ambiente seria a solução mais satisfatöria. Em ambas as situações, não se detectou a interação.

No caso 3 , os genötipos reagem diferentemente ao ambiente, sendo que um genōtipo é superior ao outro em um determinado local. Esta situação denomina-se interação simples, enquanto que, na situação 4, os genótipos trocam de posição apesar de não haver diferenças en tre ambientes. Neste caso, tem-se uma interação denominada complexa. 
Vārios autores vēm estudando o processo de interação genötipo x ambiente, dentre eles: BELL et alii (1979), com fertilizan tes em progênies; MORGENSTERN (1982), envolvendo interação entre genöti pos, sitios e tratos culturais; LAFARGE (1981) com progênies de $\underline{\text { p. taeda; }}$ GENYS (1980), com $\underline{\text { P.strobus, }}$, dentre outros.

Por sua vez, SHELBOURNE (1972) salienta que a inte ração genōtipo $\mathrm{x}$ ambiente interfere decisivamente na estratégia do progrą ma de melhoramento florestal. Deve-se, portanto, agrupar os ambientes em zonas de plantio de tal forma que haja uma mínima interação entre os sí tios e que os genótipos bem adaptados sejam selecionados visando a estabi lidade fenotípica e o crescimento vegetativo.

Os cinco tipos ou niveis de diferenças ambientais, foram caracterizados por SQUILACE (1969): entre ensaios de diferentes regiões entre sítios dentro de regiōes, dentro de pequenas áreas, entre repetições no tempo e entre ambientes artificiais.

Os efeitos da interação de genötipos e ambientes' normalmente não tēm sido levados em consideração na maioria dos trabalhos (NAMKOONG et alii, 1980). Essa interação torna-se de grande importāncia , jā que nos programas de reflorestamento são envolvidas extensas äreas, na maioria dos casos, apresentando diversidade de condições edafo-climáticas e diferentes prāticas de manejo, tais como: adubação, espaçamento, época 
de plantio, preparo de solo, etc.

FRIES (1984), citado por PATIÑO-VALERA (1986), estudou a interação genötipo $x$ espaçamento em $\underline{P}$. sylvestris L., utilizando mudas produzidas a partir de sementes e de clones enxertados, visando de tectar a ocorrēncia de interações competitivas entre elas. Embora o autor tenha encontrado interações entre o espaçamento e o grau de variação gené tica, mas para o caso da interação genótipo $x$ espaçamento não foi detectą do nenhum grau de significāncia.

\section{2 .2 - Competição intergentípica}

SAKAI (1961), denominou competição intergenotípi ca, aquela que ocorre quando as plantas em competição têm genótipos diferentes. As variações devidas ao ambiente sobrepõem-se às variações de fun do genético. Esse tipo de competição è de maior interesse para o melhoramento. Sua atuação entre as plantas pode afetar o crescimento vegetativo, e a taxa de propagação delas. Essa taxa è medida pelo nümero de plantas ' sobreviventes, ou pelo nümero de sementes produzidas pela progēnie.

A competição intergenotípica por luz, àgua, nutrientes e outros fatores de crescimento não é sempre associada a caracteres botānicos supostamente vantajosos. Isto foi demonstrado por SAKAI (1961), com doze variedades de cevada, que diferiam entre sí em diversas caracte 
rísticas botānicas. Ele observou que a competição não estā associada com porte da planta, ciclo, häbito de crescimento ou de espigamento e rendi mento. Dentro dessa mesma linha de trabalho SAKAI (1961), ao estudar as correlações entre efeitos de competição e as características botānicas , em geraçōes avançadas de cruzamentos de Oriza indica com Oriza japonica, verificou que um caracter pode estar correlacionado num cruzamento, mas não em outros.

CARDOSO e VIEIRA (1972), fizeram o uso de quatro' misturas de feijão, sendo duas delas com dois componentes (variedades) e duas com trēs componentes. Em cada caso, um igual nümero de sementes foi usado no plantio para representar cada variedade. As misturas e as variedades componentes foram analisadas por quatro plantios sucessivos, sendo determinadas as proporções em que cada variedade fazia-se representar em cada geração. Numa mistura um componente não dominou o outro. Nas outras trēs o componente mais produtivo aumentou rapidamente na população, dominando os outros. Uma mistura produziu 18,6 por cento mais do que a produção média de seus componentes, no primeiro plantio, enquanto outra mistura produziu 8,8 por cento menos. Para uso comercial os autores recomendaram usar variedades que, quando misturadas, mantivessem o equilíbrio du rante certo período.

A aplicação do método vem sendo feita hả algumas ' décadas. Chega-se com grande freqliencia a resultados indicando: 
a) um dos componentes da mistura sobressai e domi-

na os demais.

b) a mistura, quando plantada em ambientes diver sos, estabiliza a produtividade, porém a sua média raramente è superior à mëdia do melhor componente.

GUAZELLI (1975), estudando os efeitos do plantio ' de feijăo - Phaseolus vulgaris em monocultura e parcelas com misturas de variedades, concluiu que:

- a produção das variedades de feijão em misturas, pode ser maior do que a produção dessas variedades em monocultura;

- determinadas combinações de variedades em misturas mostram maior capacidade de competição. 0 estudo dos componentes da interação, variedades em monocultura e variedades em mistura, mostrou que as produções das variedades em monoculturas foi significativamente mais variāvel do que a produção em mistura;

- foi encontrada heterogeneidade dentro de varieda des para capacidade de competição. Parte dessa diferença poderia ser atrí buída à competição intergenotípica. 
18.

- foi observada interação complementar entre as quinze variedades de feijão em mistura. Isto signiflca que os ganhos obti dos em combinaçōes especificas de genötipos foram anulados por perdas ocor rentes em outras combinações.

ALLARD e ADAMS (1969), conduziram durante dois anos ensaios de quatro variedades de cevada, comparando os rendimentos em monocultura com trēs arranjos bäsicos. No primeiro deles, a variedade sob teste colocada na cova central era cercada por oito plantas da variedade competidora, numa parcela de nove covas dispostas três a trēs. No segundo arranjo a variedade sob teste na cova central era circundada por igual número de plantas da variedade teste e da variedade competidora, tendo cada ' uma, igual número de covas. Finalmente, no terceiro arranjo, a cova cen tral era cercada pelas quatro variedades do teste, sendo duas covas para cada variedade. Os resultados obtidos nos trēs arranjos foram semelhantes. $\mathrm{Na}$ maioria dos casos, os rendimentos de cada variedade, quando em copeti ção excederam, ainda que raramente de forma significativa, a produção em monocultura. O aumento médio observado, das variedades em mistura foi de menos de dois por cento num ano e menos de um por cento no ano seguinte.

$\mathrm{Na}$ mesma estação, trabalho semelhante realizado com quatro variedades de trigo mostrou incremento mëdio sob competição, da ordem de quatro por cento num ano e 4,3 por cento no ano seguinte. Os rendimentos das variedades Baart e Poso foram beneficiados por competição. No 
comportamento como vizinhos, Poso mostrou-se neutra; White Federation com portou-se como bom vizinho, mas Ramona foi o melhor vizinho, particular mente quando Baart era a variedade competidora.

Segundo MATHER (1961), a competição tem lugar en tre organismos cohabitando num ambiente, quando a soma das suas necessida des excede os suprimentos disponfiveis.

Quando as necessidades ou as atividades estão abai xo desses limites, os indivíduos podem cessar de ser parte efetiva do ambiente do outro e as suas relaçōes serão de indiferença ou neutralidade . Esta não è a ünica possibilidade. Pode acontecer que uma atividade mínima seja necessäria para que o ambiente não se situe numa condição desvantajó sa para todos os indivíduos. No caso, eles se beneficiariam da presença' mütua, ocorrendo a cooperação.

De acordo com SAKAI (1961), a competição intrageno típica ë aquela que se estabelece entre plantas duma mesma linhagem ou ' clone, devendo assim, ter o mesmo genötipo. Devido a isso, as diferenças que forem observadas no crescimento das plantas serão devidas ao ambiente variável. Seria o tipo de competição que se instalaria numa linhagem de cereal, devido ao fato de que algumas sementes terem germinado mais depressa, porque por acaso foram postas em local do solo com maior umidade. 
20.

As variações observadas não tēm causas genéticas e, por essa razāo, a sua importāncia è secundāria para os trabalhos de melhoramento das culturas.

A competição è tambèm sujeita a influēncias sistemäticas devido: a) densidade de plantio; b) fertilidade do solo; c) condi ções de cultivo.

\subsection{3 - Clones e Fertilidade do Solo}

BURDON (1971), citado por PATIÑN-VALERA (1986), tra balhando com clones de Pinus radiata em quatro sitios, na idade de doze anos, encontrou uma grande interação clone $x$ site para a frequência de ra mificação e para a retidão do tronco. Tal interação foi relacionada à deficiēncia de fósforo. A eficiēncia na absorção de fösforo apresentou-se , como sendo específica aos diferentes clones.

VENCOVSKY (1978) discute a importāncia de se conhe cer até que ponto os fatores ambientais mascaram o valor genotípico dos individuos. Assim, o autor citado mostra que quando o caráter a ser melho rado è muito influenciado pelo ambiente, deve-se utilizar um delineamento experimental adequado, um nümero suficiente de repetições e uniformizar ' ao māximo o ambiente. 
tre materiais genéticos e diferentes ambientes tēm sido comuns em muitas espëcies florestais, muito embora a quantificação desses efeitos, para ' muitas características, apresenta certas dificuldades.

PATIÑO-VALERA (1986), salienta ainda, que o ünico caminho para avaliar a presença da interação genōtipo x ambiente è instalar testes e provar os materiais genéticos em mais de um ambiente. Os autores comentam que, quando os testes são estabelecidos numa só localida de, a interação pode ficar confundida dentro do efeito genético.

Para a avaliação da interação genōtipo $\mathrm{x}$ ambiente, e para a seleção de populações visando a sua estabilidade, PATIÑo-VALERA (1986) cita os seguintes métodos:

a) classificação das mëdias de famĩlias, procedēncias ou clones nos diferentes ambientes;

b) correlação entre mëdias de procedēncias, famí lias ou clones em pares de ambientes;

c) anālises de variāncia; e

d) regressão das mēdias de famílias, procedēncias 
ou clones com os ambientes envolvendo todas as médias de todos os locais.

Segundo ZOBEL e TALBERT (1984), a interação genōtị po $\mathrm{x}$ ambiente pode levar a perdas de produtividade, tais como redução no crescimento e morte das ärvores, além de perdas na qualidade da madeira, embora as perdas de produtividade sejam mais facilmente reconhecidas.

Ainda que existam muitas causas para que ocorra a interação, ela parece estar mais relacionada com os fatores edäficos que com fatores climäticos (SHELBOURNE, 1972; GODDARD, 1977).

PATIÑO-VALERA (1986), destaca que na ocasião da escolha da melhor espëcie, deve-se levar em conta as condições climäticas e edäficas, resistēncia a pragas e a importância comercial da espécie. Co mo regra geral ē aconselhävel selecionar ärvores em solos com características semelhantes àqueles dos solos a serem reflorestados nas características bäsicas: textura, extrutura, propriedades, $\mathrm{pH}$, carbonatos e nutrien tes.

Segundo o mesmo autor, no estágio inicial dos programas de melhoramento, deve-se lembrar que ärvores geneticamente inferio res crescendo em solos fërteis podem ter muito melhor aparēncia do que ār vores geneticamente superiores crescendo em solos de baixa fertilidade. 
Portanto, a escolha de ärvores superiores, para o melhoramento, não pode ser consumada sem estudo da capacidade de produtividade do solo.

BARNES et alii (1983), concluiram que a produção ' de ärvores florestais estā intimamente ligada a uma resposta fisiológica em crescimento. Esta resposta è função da atuação positiva ou negativa de vārios fatores, como por exemplo: solo, clima, competição, patógeno, tratos silviculturais, etc.

Ainda os mesmos autores acrescentam que para se ob ter a mäxima produção, será necessäria uma manipulação da parte genética destes efeitos. Contudo, essa manipulação irá requerer conhecimentos de como as variações ocorrem na espëcie.

Sabe-se que as diferentes características qualitativas e quantitativas de interesse do melhoramento apresentam graus dis tintos de interações, ou seja, hả características que sofrem mais o efeito do ambiente do que outras. Características comandadas por poucos genes apresentam um maior controle genético, sendo assim menos afetados pelo am biente, mostrando-se mais estäveis em diversos sítios. Jä características sob controle de muitos genes ocorre o inverso, hä pouco controle genético e o ambiente influencia bastante. 
de uma planta em um dado sítio é determinado pela interação das caracterís ticas inerentes à planta, como por exemplo, o seu potencial genético com ' os fatores ambientais. Assim, do ponto de vista de eficiēncia nutricional, - melhor crescimento de um genötipo pode ser decorrente de sua maior capacidade de absorção de nutrientes do solo ou da sua maior eficiência em uti lizar o nutriente absorvido na produção de matëria seca. Tais característí cas não tēm sido levadas em conta no processo de seleção de Eucalyptus no Brasil. A primeira característica è importante em se considerando a necessidade de aumentar a taxa de recuperação de elementos aplicados, por exemplo via adubação. Entretanto ela pode ser menos desejāvel em relação à segunda, quando se considerar que o crescimento florestal deve ser suportado pelas reservas de nutrientes naturalmente existentes no solo. Assim permitiria uma melhor adequação do genótipo, quanto às suas exigēncias nutricio nais, à capacidade de sustentação do sítio, isto é, genótipos mais exigentes, por exemplo, em potássio seriam plantados em sítios mais ricos neste elemento. Caso conträrio, eles teriam necessariamente que receber maior ! quantidade do nutriente, via fertilizante, do que um genötipo menos exigen te.

Em termos fisiolögicos, a interação genötipo $x$ eficiēncia nutricional pode ser determinada por um ou mais dos seguintes meca nismos (Graham, 1984, citado por BARROS, 1986).

a) maior crescimento e geometria do sistema radicu- 
lar;

b) taxa de absorção específica mais rāpida a bai xas concentrações;

c) modificação química no solo próximo à raiz para maior solubilização dos nutrientes mais limitantes;

d) eficiente redistribuição interna do nutriente;

e) melhor utilização ou um menor requerimento funciona1 do nutriente.

KAGEYAMA (1986) destaca que de uma forma muito genérica, a interação genótipos $x$ ambientes pode ser utilizada de duas formas para o zoneamento ecológico de determinados materiais genéticos (espé cies, procedēncias, progēnies e clones) e para a estratificação da sele ção de indivíduos superiores num programa de melhoramento.

Diferentes materiais genëticos manifestam-se dife renciadamente quanto à interação. De um modo geral, quanto mais amplos ou mais variados os materiais genéticos, menor a manifestação de sua intera- 
ção com a mudança no ambiente, e vice-versa. Por outro lado, quanto mais controlado o ambiente (maior uso de tecnologia silvicultural) menor serä a manifestação da interação. Daf a maior magnitude da interação, no geral, em silvicultura do que em agricultura. Espēcies / procedēncias mais "rūs ticas" mostram que a maior capacidade de absorção de nutrientes pela plan ta seria muito importante nos povoamentos recém-implantados, -enquanto que uma maior eficiência de utilização seria desejāvel durante toda a vida da ärvore. BARROS (1986) destaca, também, que o reconhecimento destas duas ' características è particularmente importante para os solos brasileiros. que são relativamente pobres em nutrientes, e a seleção de indivíduos com maior eficiēncia nutricional poderà significar não só uma possível econo mia de fertilizantes, mas principalmente a manutenção da produtividade flo restal do sítio por um período de tempo mais longo.

\section{0 mesmo autor destaca também que os resultados so} bre a interação nos seus diferentes níveis vēm mostrando que ela è muito mais importante do que se imaginava. Isso revela que o conceito de que os sistemas genēticos florestais são muito "plāsticos", ou que se adap tam a amplas condições ecolögicas, nem sempre è verdadeiro. Esses resultados tëm mostrado que em muitos casos o trabalho de seleção no melhoramento pode ser facilmente solapado pela interação, quando se faz a extra polação dos resultados de um ambiente especifico para outro. 
3. MATERIAL E METODOS

\section{1 - Material}

\section{1 .1 - Localização dos Ensaios}

Em agosto de 1984 escolheram-se as Fazendas Pirace ma e Rio Claro, localizadas na região de Lençóis Paulista, Estado de São Paulo, por apresentarem características climäticas semelhantes e diferenças bastante grandes quanto aos aspēctos físicos e químicos do solo.

\subsection{2 - Características climäticas}

- Latitude: $22^{\circ} 45^{\prime}$

- Longitude: $48^{\circ} 49^{\prime}$

- Altitude: $600 \mathrm{~m}$

- Precipitação mëdia de $1.200 \mathrm{~mm} / a n o$, temperatura médiamáxima de $27,3^{\circ}$ e temperatura média mínima de $13,0^{\circ} \mathrm{C}$. 


\subsection{3 - Material genético empregado}

a) SEMENTES COMERCIAIS: escolheu-se em Junho de 1982, aleatoriamente, junto aos povoamentos comerciais da DURATEX FLORESTAL S.A. em Lençóis Paulista - S.P., a quadra 231 plantada atravēs de mudas produzidas por sementes importadas de Eucalyptus grandis - ex. Årica do Sul (base genética desconhecida). Colheu-se sementes de 50 ärvores tomadas ao acaso na população. 0 solo predominante na ärea é a Areia Quartị zosa Álica. O espaçamento original foi de $3,0 \mathrm{~m} \times 1,5 \mathrm{~m}$. Na época do corte, as ärvores estavam com 6,5 anos, altura mëdia de $22,9 \mathrm{~m}$, diāmetro à altura do peito (DAP) de $16,6 \mathrm{~cm}$ e $12,6 \%$ de falhas, com produtividade média de 79,9 estéreos (st)/ha/ano.

b) SEMENTES DE POMAR CLONAL: colheu-se na fazenda PIRACEMA, região de Lençōis Paulista, em äreas da DURATEX FLORESTAL S.A., sementes de enxertos plantados em espaçamento de 5,0 m x 2,5 m e produzidos com ramo-enxertos colhidos em ärvores selecionadas em povoamentos comerciais de E. grandis - ex. Coff's Harbour, na região de Salto - S.P. , com Índice de seleção de $1: 1.600$.

No referido pomar clonal foram plantados 1000 en xertos (100 matrizes), em fevereiro de 1979.

c) SEMENTES DE ÁRVORES MATRIZES: na fazenda Rio Cla ro foram selecionados oito ärvores que por seu vigor, retidāo do fuste, re 
sistēncia à pragas e doenças, características favoräveis quanto à desrama natural e volume de copa se destacavam das demais existentes nos povoamen tos comerciais da DURATEX FLORESTAL S.A.

As ärvores de E. grandis apresentavam-se na ëpoca da seleção com 7,9 a 8,4 anos, tendo sido plantadas a partir de sementes, em espaçamento de $3,0 \mathrm{~m} \times 1,5 \mathrm{~m}$. A altura mëdia dos povoamentos estava' compreendida na faixa de $17,5 \mathrm{~m}$ a $23,0 \mathrm{~m}$, O DAP de $11,5 \mathrm{~cm}$ a $14,2 \mathrm{~cm}$ e a produtividade de 44,7 st/ha/ano à 98,2 st/ha/ano.

d) CLONES PROPAGADOS POR ESTAQUIA: após o abate ' das ärvores matrizes (item c), coletou-se material vegetativo proveniente da rebrota das oito touças. A partir desse material foram produzidas mudas em condições controladas de casa de vegetação.

\section{1 .4 - Caracterização do Solo}

a) ENSAIO DA FAZENDA RIO CLARO

a.1) Descrição Morfolögica

- Classificação: Podzölico vermelho escuro ( $\mathrm{V}$ E) eutröfico A moderado, textura média (RANZANI - 1962).

- Relevo local: plano 
- Relevo regional: suave ondulado

- Material de origem: arenito Bauru

- Drenagem: boa

- HORIZONTE AP: 0-16 cm, 2,5 YR 3/2, barro argilo' arenoso, moderada a fraca, peque nas, granular e blocos, muito friā vel, ligeiramente plästico e ligei ramente pegajoso, transição clara, ondulada, raizes abundantes muito finas a médias.

- HORIZONTE A3: 16-33 cm, 2,5 YR 3/4 (2,5 YR 2/4), barro argilo arenoso, maciço coeso, muito duro, friāvel, plástico e pe gajoso, transição difusa e plana, raízes poucas e finas.

- HORIZONTE B $21: 33-85 \mathrm{~cm}, 2,5$ YR 3/4 (2,5 YR 3/4), barro argilo argiloso, moderada, mé dio, prismātica, duro, muito friāvel, plástico e pegajoso, transi ção difusa e plana, raízes comuns, muito finas e finas.

OBS.: acumulação de argila no topo $\mathrm{B}_{21}$

- HORIZONTE $B_{22}: 85-148 \mathrm{~cm}, 2,5$ YR $3 / 6(2,5 \mathrm{YR} 3 / 4)$ barro argilo argiloso, moderada, medio, prismas e blocos, duro, muito friävel, plāstico e pegajoso,tran- 
sição difusa e plana, raízes co muns.

- HORIZONTE B 3 : $148 \mathrm{~cm}+, 2,5$ YR 3/6 (2,5 YR 3/4), barro argiloso, maciça porosa, 1igeiramente duro, muito friävel, $1 \underline{i}$ geiramente plāstico e pegajoso, ' transição difusa e plana, raízes comuns.

b) ENSAIO DA FAZENDA PIRACEMA

1. Descrição Morfolögica

- Classificação: Areia Quartzosa Âlica (A.Q.) (RANZANI - 1962)

- Relevo local: plano

- Relevo regiona1: suavemente ondulado

- Material de origem: arenito Bauru

- Drenagem: boa

- HORIZONTE Ap: 0-17 cm, 10 YR 5/3, areia, maciçaporosa, que se desfaz em grãos sim ples, solto, muito friāve1, não' plästico e não pegajoso, transição 
32.

gradual e plana, raizes abundantes médias a finas.

- HORIZONTE A3: 17-42 cm, 10 YR 5/3 (10 YR 4/3), areia, maciça porosa que se desfaz em grãos simples, solto, muito fri ável, não plástico e não pegajoso, transição difusa e plana, raízes ' abundantes mëdias e finas.

- HORIZONTE $\mathrm{C}_{1}: 42-128 \mathrm{~cm}, 10 \mathrm{YR}$ 6/4 (10 YR 4/4), areia, maciça porosa que se desfaz en grãos simples, solto, muito fri àvel, não plāstico e não pegajoso, transição difusa e plana, rajzes ' abundantes mëdias e finas.

- HORIZONTE $\mathrm{C}_{2}: 128-160 \mathrm{~cm}+, 10 \mathrm{YR}$ 5/4 (10 YR 4/4) areia, maciça que se desfaz em ' grãos simples, solto, muito friā vel, não plästico e não pegajoso, raizes abundantes mëdias e finas.

\section{2 - Métodos}

\subsection{1 - Präticas Silviculturais Adotadas}

a) Anälise do Solo 
Nos dois locais onde foram instalados os ensatos, coletou-se em cada um dos 16 tratamentos uma amostra simples de solo em três profundidades: 0 a $30 \mathrm{~cm}, 30$ a $60 \mathrm{~cm}$ e $60 \mathrm{~cm}$ a $100 \mathrm{~cm}$. As amostras simples foram homogeneizadas formando-se uma amostra composta em cada uma das trēs profundidades para anälises físicas e químicas em laboratörio.

Nas quadras onde foram selecionadas as oito ärvores matrizes retiraram-se dez amostras simples por quadra nas três pro fundidades ( 0 a $30 \mathrm{~cm}, 30$ a $60 \mathrm{~cm}$ e $60 \mathrm{~cm}$ a $100 \mathrm{~cm}$ ), para que posteriormente fossem formadas as amostras compostas por profundidade e por qua dra.

b) Produção das Mudas

As mudas propagadas via sementes foram produzidas no viveiro de mudas da DURAFLORA pelo sistema comercial da empresa, utilizando a semeadura direta em sacos de polietileno de $12 \mathrm{~cm}$ de altura $\mathrm{x}$ $6 \mathrm{~cm}$ de diémetro e recebendo 1 g/recipiente de adubo granulado NPK - 10: 28:6 + Boro e Zinco. 0 tempo de produção das mudas foi de 90 dias. As mu das foram produzidas por estaquia e tiveram o material colhido nas touças apös trēs meses do corte dás ärvores. Padronizou-se o tamanho das es tacas em $12 \mathrm{~cm}$, recebendo em sua base uma película de A.I.B. - Ácido Indol Butírico visando a facilitar o enraizamento. 
As estacas foram tambëm colocadas em sacos de polietileno de $12 \mathrm{~cm} \mathrm{x} 6 \mathrm{~cm}$ e preenchidos com substrato areno-argiloso.

o tempo de produção das mudas em casa de vegetação, com temperatura oscilando entre $25-30^{\circ} \mathrm{C}$ e umidade relativa média de 70\%, foi de 90 dias. O plantio foi realizado em Agosto de 1984.

c) Preparo de Solo

Efetou-se duas gradagens empregando-se grades com aproximadamente $800 \mathrm{~kg}$ e 10 discos de $45 \mathrm{~cm}$ de diämetro.

d) Espaçamento e Adubação

0 espaçamento foi de $3,0 \mathrm{~m} \times 3,0 \mathrm{~m}$ e a adubação' de $200 \mathrm{~kg} / \mathrm{ha}(180 \mathrm{~g} / \mathrm{planta})$ da formulação NPK $-10: 28: 6+\mathrm{B}+\mathrm{Zn}$.

e) Manutenção

Foram feitas duas capinas manuais e uma química, utilizando 1 litro/ha do produto à base de GLIFOSATO, de nome comercial' ROUNDOP, produzido pela MONSANTO DO BRASIL S.A. 


\section{2 .2 - Tratamentos}

\begin{tabular}{rlll}
\hline No & \multicolumn{2}{c}{ ESPECIFICAÇÃo } & LEGENDA \\
\hline 1 & Parcela Monoclonal & Clone G 0245 & A \\
2 & Parcela Monoclonal & Clone G 0246 & A \\
3 & Parcela Monoclonal & Clone G 0269 & A \\
4 & Parcela Monoclonal & Clone G 0250 & A \\
5 & Parcela Monoclonal & Clone G 0256 & A \\
6 & Parcela Monoclonal & Clone G 0258 & A \\
7 & Parcela Monoclonal & Clone G 0261 & A \\
8 & Parcela Monoclonal & Clone G 0251 & B \\
9 & Parcela Multiclonal & & B \\
10 & Parcela Multiclonal & & B \\
11 & Parcela Multiclonal & & C \\
12 & Sementes de P.S. Clonal & & C \\
13 & Sementes de P.S. Clonal & D \\
14 & Sementes das árvores matrizes & D \\
15 & Sementes das ärvores matrizes & E \\
16 & Sementes Comerciais DURAFLORA & \\
\hline
\end{tabular}

LEGENDA

A - Parcélas de oito clones, plantadas separadamente e consti tuidas por plantas propagadas por estaquia.

B - Parcelas multiclonais distribuidas ao acaso e constituidas por plantas dos mesmos oito clones das parcelas monoclonais. 
36.

C - Parcelas constituídas por plantas originärias de pomar de sementes clonal propagado por enxertia cujas ärvores foram selecionadas na regiāo de Salto - S.P.

D - Parcelas constituidas por plantas produzidas por sementes ' das oito ärvores selecionadas de cujas touças retiraram-se estacas.

E - Parcelas constituídas por plantas originärias de sementes ' de E. grandis - Ex. África do Sul e colhidas em povoamentos comerciais da DURATEX FLORESTAL S.A. na região de Lençōis ' Paulista - S.P.

\subsection{3 - Delineamento Estatístico}

Utilizou-se o delineamento de blocos ao acaso, com 16 tratamentos e 3 repetiçōes. As parcelas foram constituídas de 36 plantas, sendo mensuräveis as 16 centrais.

\subsection{4 - Esquema de Anälise Estatística}

a) Anālise de Variāncia Individual 


\begin{tabular}{lc}
\hline Fonte de Variação & Graus de Liberdade \\
\hline Repetições & 2 \\
Tratamentos & 15 \\
Erro & 30 \\
TOTAL & 47 \\
\hline
\end{tabular}

b) Anālise de Variāncia Conjunta

\begin{tabular}{lc}
\hline Fonte de Variação & Graus de Liberdade \\
\hline Solos & 1 \\
Repet. / Exper. & 4 \\
Tratamentos & 15 \\
Tratam. / Solos & 15 \\
Erro Médio & 60 \\
TOTAL & 95 \\
\hline
\end{tabular}

\subsection{5 - Area do Ensaio}

- Espaçamento: 3,0 m x 3,0 m

- Area da Parcela: $324 \mathrm{~m}^{2}$

- Área de um Ensaio: $15.552 \mathrm{~m}^{2}$ 
38.

- Ârea dos dois Ensaios: $31.104 \mathrm{~m}^{2}$

\subsection{6 - Coleta de Material Vegetativo para Anälise}

Em Agosto de 1985, época em que os ensaios apre sentavam um ano de idade, coletou-se material vegetativo visando a anälise foliar em laboratōrio.

A metodologia empregada seguiu orientação de HAAG (1985), ou seja:

- Coleta de 100 folhas de cada tratamento em todas as repetições, compondo uma amostra composta das 16 ärvores centrais da parcela.

- Amostragem no terço médio das ärvores.

- Coleta na direção dos quatro pontos cardeais.

- Folhas no estāgio de desenvolvimento recém-ma duro ( 3 a ou 4 a folha). 
- 0 material foi colocado em sacos de papel, amar rado, etiquetado e enviado ao laboratório do Departamento de Química da ESALQ - Escola Superior de Agricultura "Luiz de Queiroz" em Piracicaba S.P.

3.2.7 - Coleta de Dados no Campo

Foram coletados nas diferentes idades as seguin tes informações:

\begin{tabular}{cl}
\hline IDADE & \multicolumn{1}{c}{ PARAMETROS } \\
\hline 30 dias & Sobrevivēncia \\
6 meses & Sobrevivência e altura \\
12 meses & Sobrevivēncia e altura \\
18 meses & Sobrevivência, altura e DAP \\
24 meses & Sobrevivēncia, altura e DAP \\
\hline
\end{tabular}


40 .

4. RESULTADOS E DISCUSSÃO

\section{1 - Consideraçōes sobre o melhoramento genético}

\subsection{1 - Sobrevivência}

$\mathrm{Na}$ avaliação da porcentagem de falhas aos vinte e quatro meses apresentada na Tabela 2, observa-se que no solo Podzólico' Vermelho Escuro ( $P V E$ ) houve uma variação de 0,0\% (trat. 15 - sementes de matrizes) à 18,8\% (trat. 4 - clone G 0250 e trat. 7 - clone G 0261), ficando a média do ensaio em 7,6\%

Pelo teste TUKEY(dados transformados em: arc sen

$\sqrt{x+0,5}$ ) não houve diferenças significativas à $5 \%$, podendo este fato ser explicado pelo alto coeficiente de variação na anälise de variāncia: $(70,98 \%)$. O valor do teste $F$ foi 2,37 . 


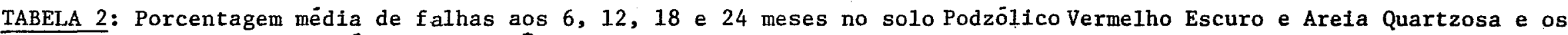
resultados da Anälise de Variancia.

\begin{tabular}{|c|c|c|c|c|c|c|c|c|}
\hline \multirow{3}{*}{ TRATAMENTO } & \multicolumn{4}{|c|}{ PODZOLICO VERMELHO ESCURO } & \multicolumn{4}{|c|}{ AREIA QUARTZOSA } \\
\hline & \multicolumn{4}{|c|}{ IDADE (MESES) } & \multicolumn{4}{|c|}{ IDADE (MESES) } \\
\hline & 6 & 12 & 1.8 & 24 & 6 & 12 & 18 & 24 \\
\hline 01 - Clone G-0245 & $4,2-A$ & $8,3-A$ & $8,3-A B$ & $8,3-A$ & $2,1-A$ & $2,1-A$ & $2,1-A$ & $2,1-A$ \\
\hline 02 - Clone G-0246 & $8,3-A$ & $10,4-A$ & $10,4-\mathrm{AB}$ & $10,4-A$ & $4,2-A$ & $4.2-A$ & $4,2-A$ & $4,2-A$ \\
\hline 03 - Clone G-0269 & $2,1-A$ & $2,1-A$ & $2,1-\mathrm{AB}$ & $2,1-A$ & $6,3-A$ & $6,3-A$ & $6,3-A$ & $6,3-A$ \\
\hline 04 - Clone G-0250 & $12,5-A$ & $18,8-A$ & $18,8-A$ & $18,8-\mathrm{A}$ & $6,3-A$ & $8,3-A$ & $8,3-A$ & $8,3-A$ \\
\hline 05 - Clone G-0256 & $12,5-\mathrm{A}$ & $12,5-\mathrm{A}$ & $12,5-A B$ & $12,5-\mathrm{A}$ & $0,0-A$ & $0,0-A$ & $0,0-A$ & $0,0-A$ \\
\hline 06 - Clone G-0258 & $12,5-\mathrm{A}$ & $10,4-\mathrm{A}$ & $12,5-\mathrm{AB}$ & $12,5-\mathrm{A}$ & $10,4-A$ & $10,4-A$ & $10,4-A$ & $10,4-A$ \\
\hline 07 - Clone G-0261 & $18,8-A$ & $18,8-A$ & $18,8-A$ & $18,8-A$ & $6,3-A$ & $6,3-A$ & $6,3-A$ & $6,3-A$ \\
\hline 08 - C1one G-0251 & $2,1-A$ & $2,1-A$ & $2,1-A B$ & $4,2-A$ & $8,3-A$ & $8,3-A$ & $8,3-A$ & $14,6-\mathrm{A}$ \\
\hline 09 - Multiclones & $6,3-A$ & $6,3-A$ & $6,3-A B$ & $6,3-A$ & $2,1-A$ & $2,1-A$ & $2,1-A$ & $2,1-A$ \\
\hline 10 - Multiclones & $8,3-A$ & $8,3-A$ & $8,3-A B$ & $8,3-A$ & $0,0-A$ & $0,0-A$ & $0,0-A$ & $0,0-A$ \\
\hline 11 - Multiclones & $4,2-A$ & $6,4-A$ & $6,4-A B$ & $6,4-A$ & $6,3-A$ & $8,3-A$ & $8,3-A$ & $8,3-A$ \\
\hline 12 - Sem.Pomar clonal & $2,1-A$ & $2,1-A$ & $2,1-A B$ & $2,1-A$ & $0,0-A$ & $0,0-A$ & $0,0-A$ & $0,0-A$ \\
\hline 13 - Sem.Pomar clonal & $2,1-A$ & $4,1-A$ & $4,1-A B$ & $6,3-A$ & $0,0-A$ & $2,1-A$ & $2,1-A$ & $2,1-A$ \\
\hline 14 - Sementes Matrizes & $2,1-A$ & $2,1-A$ & $2,1-A B$ & $2,1-A$ & $0,0-A$ & $0,0-A$ & $0,0-A$ & $0,0-A$ \\
\hline 15 - Sementes Matrizes & $0,0-A$ & $0,0-A$ & $0,0-B$ & $0,0-A$ & $0,0-A$ & $0,0-A$ & $0,0-A$ & $0,0-A$ \\
\hline 16 - Sementes Comercial & $2,1-A$ & $2,1-A$ & $2,1-A B$ & $2,1-A$ & $0,0-A$ & $0,0-A$ & $0,0-A$ & $0,0-A$ \\
\hline Valor de F & $2,10 *$ & $2,43 *$ & $2,07 *$ & $2,37^{*}$ & $2,37 *$ & $2,07^{\star}$ & $2,07 *$ & $2,67^{*}$ \\
\hline Coef. de Variação & $89,04 \%$ & $72,83 \%$ & $115,97 \%$ & $70,98 \%$ & $117,17 \%$ & $115,97 \%$ & $115,97 \%$ & $105,60 \%$ \\
\hline
\end{tabular}

TRATAMENTOS COM LETRAS COMUNS NÃO DIFEREM A 5\% PELO TESTE TUKEY.

* Significativas a $5 \%$ pelo teste F 
Na areia quartzosa ( $A Q)$, a mëdia de falhas foi de $4,0 \%$, variando de $0,0 \%$ (trat. $5,14,15$ e 16) a 10,4\% (trat. 6 - clone G 0258). O teste TUKEY não mostrou diferenças significativas a 5\%, sendo que o coeficiente de variação foi muito alto $(105,60 \%)$ e o valor do teste $\mathrm{F}$ igual a 2,67.

No Gräfico 1 observa-se que no PVE aos 12 meses, as parcelas de sementes de matrizes apresentaram apenas $1 \%$ de falhas, fi cando a mëdia dos monoclones com o maior indice, 10,9\%. As parcelas oriundas de sementes de pomar clonal (P.S.C.) apresentaram 4,2\%, as oriun das de sementes comerciais $2,0 \%$, as de multiclones $6,9 \%$, e as do melhor clone (G 0269), apenas $2,1 \%$. Na areia quartzosa as parcelas de sementes' comerciais e de matrizes não mostraram falhas, as de P.S.C. apenas $1 \%$, as de multiclones $3,5 \%$, as de monoclones $6,5 \%$ e o melhor clone (em volume) apenas $6,3 \%$ de falhas.

Apesar de não haver diferenças significativas entre mëdias de sobrevivēncia, as parcelas com clones apresentaram maior nümero de falhas ém relação às propagadas por sementes.

$$
4.1 .2 \text { - Altura }
$$

Analisando os dados da Tabela 3, observa-se que a superioridade na característica altura de um tratamento em relação ao ou 
GRAFICO 1: Porcentagem mëdia de falhas dos diferentes materiais genéticos, aos dois anos de idade nos dois locais.

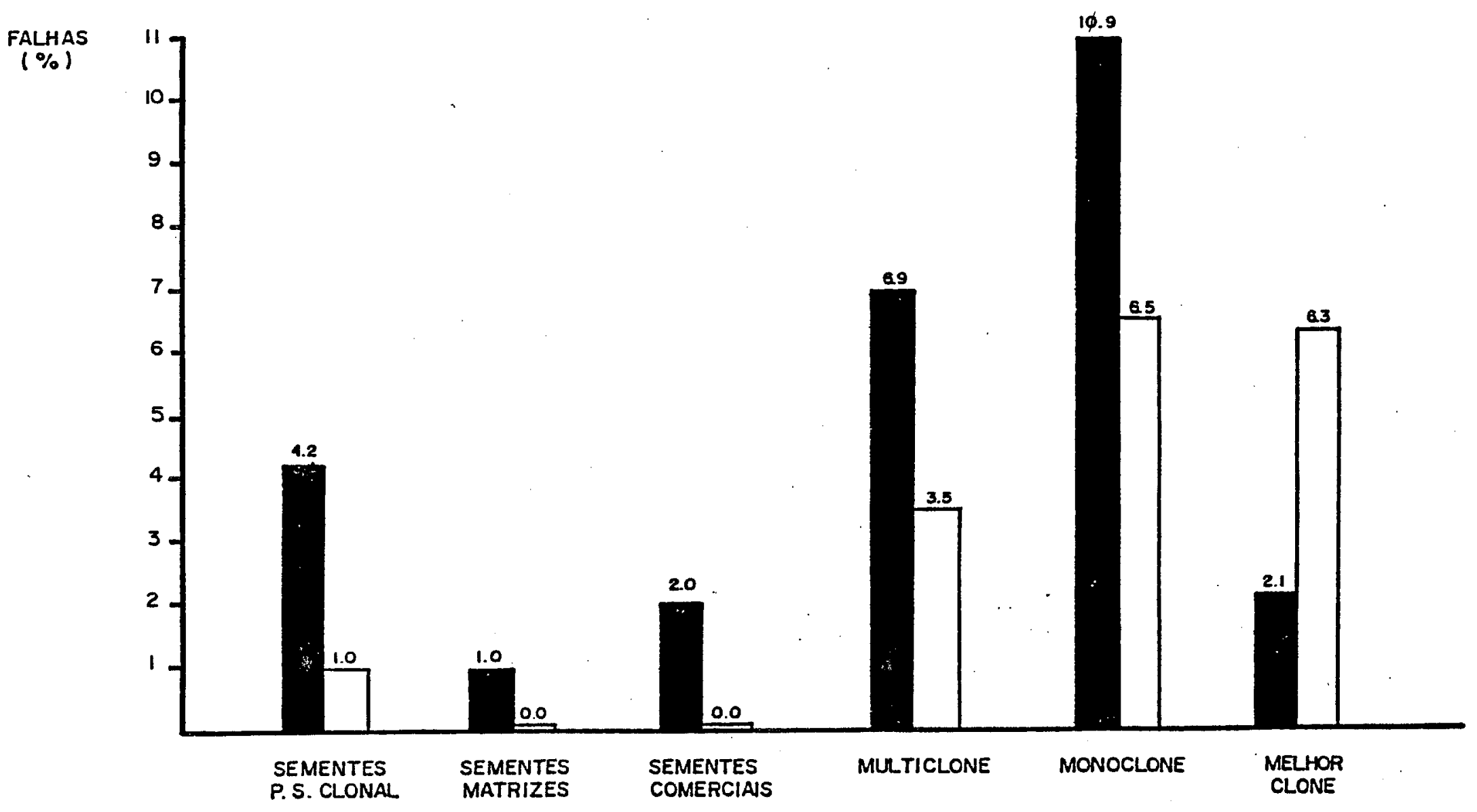

SOLO: LATOSSOLLICO VERMELHO ESCURO

AREIA QUARTZOSA 
44 .

tro se manteve na mesma proporção desde os 12 aos 24 meses, nos dois solos (PVE e AQ).

No PVE a média de altura foi $12,6 \mathrm{~m}$, variando de 11,4 (trat. 7 - clone G 0261) a 13,7 m (trat. 13 - Pomar de sementes clo na1), não ocorrendo diferenças estatísticas ao nível de $5 \%$ de significān cia pelo teste TUKEY. Na anālise de variäncia o coeficiente de variação, aos 24 meses, foi de $7,55 \%$ e o valor do teste $F$ igual a 9,30 .

\begin{abstract}
$\mathrm{Na} A Q$ a média de altura foi de $10,4 \mathrm{~m}$, variando ' de 9,3 m (trat. 07 - clone G 0261) a 11,7 m (trat. 13 - P.S. C1ona1).
\end{abstract}

Tais diferenças não foram significativas a $5 \%$ pe1o teste TUKEY. Na anālise de variāncia o coeficiente de variāncia foi de $6,13 \%$ e o valor de $F$ igual a 2,90 .

Na comparação de altura entre os diferentes materiais genëticos téstados na idade de dois anos, atravēs do Gräfico 2, ob serva-se que tanto os materiais originärios de sementes, como os propaga dos por estacas apresentaram muita similaridade.

No PVE a altura média das plantas para as parce las originärias de P.S.C. foi de $13,6 \mathrm{~m}$, para as parcelas de sementes de 
TABELA 3: Altura (m) aos 12, 18 e 24 meses na Areia Quartzosa e Podzólico Vermelho Escuro e os resultados da Anälise de Variāncia.

\begin{tabular}{|c|c|c|c|c|c|c|}
\hline \multirow{3}{*}{ TRATAMENTO } & \multicolumn{3}{|c|}{ PODZOLICO VERMELHO ESCURO } & \multicolumn{3}{|c|}{ AREIA QUARTZOSA } \\
\hline & \multicolumn{3}{|c|}{ IDADE (MESES) } & \multicolumn{3}{|c|}{ IDADE (MESES) } \\
\hline & 12 & 18 & 24 & 12 & 18 & 24 \\
\hline 01 - Clone G-0245 & $5,6-\mathrm{DE}$ & $8,1-D E$ & $11,5-B$ & $4,5-D E$ & $7,1-C D$ & $9,5-B C$ \\
\hline 02 - Clone G-0246 & $6,0-B C D$ & $8,7-\mathrm{CDE}$ & $12,5-A B$ & $5,3-A B C D E$ & $8,0-A B C D$ & $10,5-A B C$ \\
\hline 03 - Clone G-0269 & $6,3-\mathrm{ABCD}$ & $9,5-A B C$ & $13,1-A B$ & $5,6-\mathrm{ABCD}$ & $8,6-A B C$ & $10,8-A B C$ \\
\hline 04 - Clone G-0250 & $6,3-A B C D$ & $9,7-A B C$ & $13,4-\mathrm{A}$ & $4,8-\mathrm{CDE}$ & $8,0-A B C D$ & $10,6-A B C$ \\
\hline 05 - Clone G-0256 & $5,8-\mathrm{DE}$ & $8,7-\mathrm{CDE}$ & $12,8-A B$ & $4,6-\mathrm{DE}$ & $7,6-\mathrm{ABCD}$ & $10,6-\mathrm{ABC}$ \\
\hline 06 - Clone G-0258 & $5,7-D E$ & $9,0-B C D E$ & $12,8-A B$ & $4,5-D E$ & $7,5-B C D$ & $10,1-A B C$ \\
\hline 07 - Clone G-0261 & $5,0-E$ & $7,8-E$ & $11,4-B$ & $4,1-E$ & $6,8-D$ & $9,3-c$ \\
\hline 08 - Clone G-0251 & $5,9-D E$ & $8,6-\mathrm{CDE}$ & $12,6-A B$ & $4,5-D E$ & $7,3-\mathrm{CD}$ & $10,1-A B C$ \\
\hline 09 - Multiclones & $5,9-C D E$ & $9,0-\mathrm{BCDE}$ & $12,5-A B$ & $5,1-\mathrm{ABCDE}$ & $8,2-A B C D$ & $10,4-\mathrm{ABC}$ \\
\hline 10 - Multiclones & $5,9-C D E$ & $8,8-C D E$ & $12,5-A B$ & $5,2-\mathrm{ABCDE}$ & $7,8-\mathrm{ABCD}$ & $9,9-\mathrm{ABC}$ \\
\hline 11 - Multiclones & $6,3-A B C D$ & $8,8-\mathrm{CDE}$ & $12,2-A B$ & $5,0-\mathrm{BCDE}$ & $7,6-\mathrm{BCD}$ & $9,8-\mathrm{BC}$ \\
\hline 12 - Sem.Pomar clonal & $7,0-A B$ & $10,2-A B$ & $13,6-\mathrm{A}$ & $6,3-A$ & $9,3-A$ & $11,3-A B$ \\
\hline 13 - Sem. Pomar clonal & $7,2-A$ & $10,6-A$ & $13,7-A$ & $6,1-\mathrm{AB}$ & $9,1-A B$ & $11,7-A$ \\
\hline 14 - Sementes Matrizes & $6,9-A B C$ & $9,5-\mathrm{ABC}$ & $12,7-A B$ & $5,8-A B C$ & $8,5-A B C$ & $10,7-\mathrm{ABC}$ \\
\hline 15 - Sementes Matrizes & $7,0-A$ & $9 ; 4-A B C D$ & $12,9-A B$ & $6,3-A$ & $8,8-A B C$ & $11,1-A B C$ \\
\hline 16 - Semente Comercial & $6,3-A B C D$ & $8,8-\mathrm{CDE}$ & $12,4-\mathrm{AB}$ & $6,0-A B C$ & $8,6-A B C$ & $10,7-A B C$ \\
\hline Valor de $F$ & 9,30 & 6,81 & 3,22 & 9,30 & 5,36 & 2,90 \\
\hline Coef. de Variação & $5,19 \%$ & $4,94 \%$ & $4,73 \%$ & $7,55 \%$ & $6,94 \%$ & $6,13 \%$ \\
\hline
\end{tabular}


46.

matrizes $12,8 \mathrm{~m}$, para as parcelas originärias de sementes comerciais ' $12,4 \mathrm{~m}$, para os multiclones $12,4 \mathrm{~m}$, para os monoclones $12,5 \mathrm{~m}$ e para o melhor clone (G 0250) 13,4m.

$\mathrm{Na} \mathrm{AQ}$ as parcelas com sementes de P.S.C. cresce ram $11,5 \mathrm{~m}$, as de sementes de matrizes $10,9 \mathrm{~m}$, as de sementes comerciais, $10,7 \mathrm{~m}$, os multiclones $10,0 \mathrm{~m}$, os monoclones $10,2 \mathrm{~m}$ e o melhor clone ( $\mathrm{G}$ 0269) $10,8 \mathrm{~m}$.

Observa-se, porēm, que nos dois solos (PVE e AQ), as parcelas oriundas de sementes de pomar clonal superaram os clones, até a idade de 24 meses. Observa-se também que o melhor clone equivale em a1 tura às parcelas oriundas de sementes de pomar clonal.

Analisando ainda a caracterísita altura no Gráfí co 2, verifica-se que não houve grandes mudanças de 12 para 24 meses no que se refere à superioridade do mesmo material quando se comparou os dois solos. Assim, aos 12 meses, as parcelas com sementes de pomar clo nal no PVE eram superiores à AQ em 21,7\%; aos 24 meses, a superioridade' foi de $18,3 \%$. Este fato pode ser observado para os demais materiais gené ticos testados. 


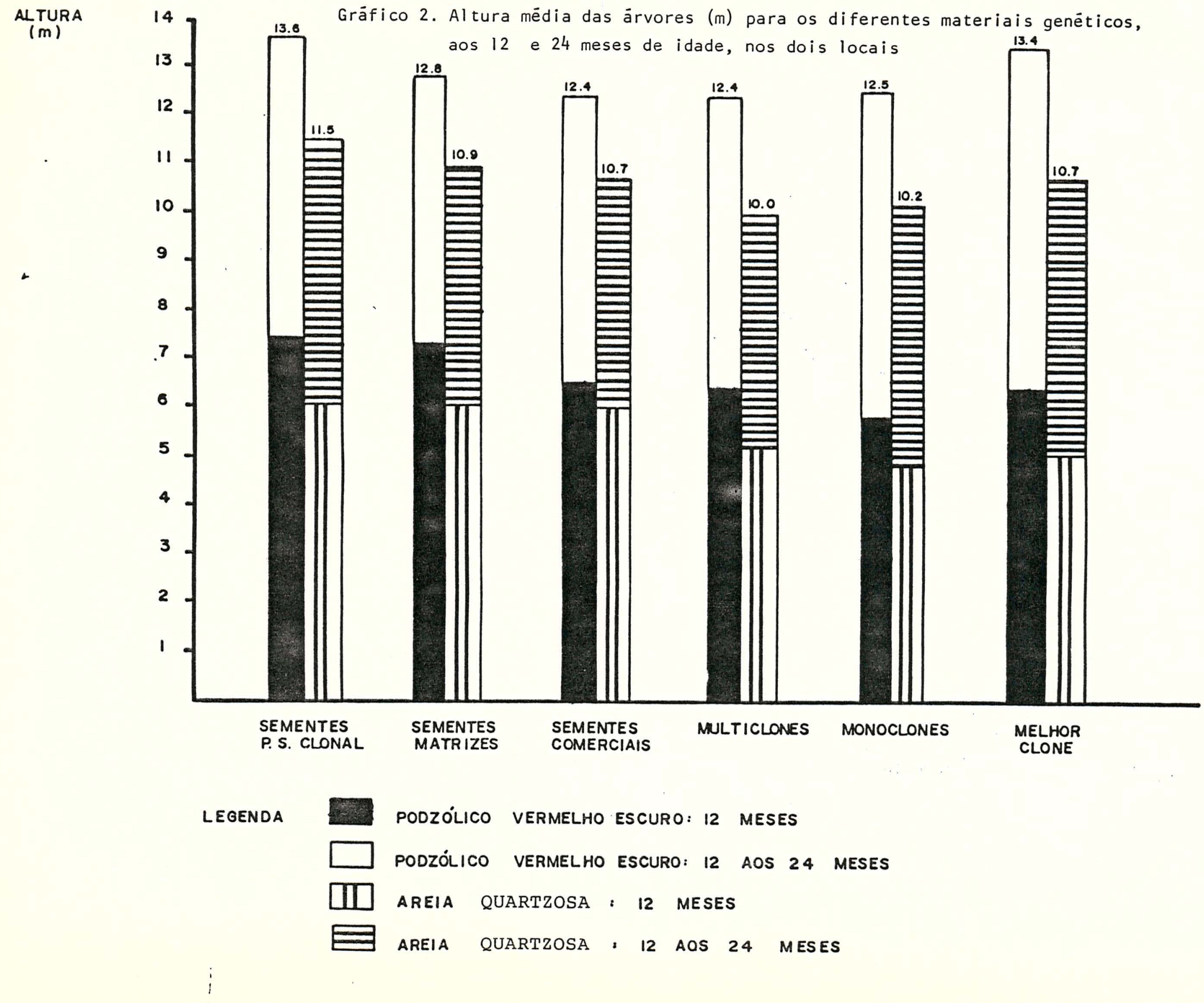




\subsection{3 - Diâmetro a altura do peito (DAP)}

Na anälise do DAP, através do auxilio da Tabela 4, observa-se que dos 18 aos 24 meses a proporção de crescimento entre os tratamentos permaneceu praticamente constante.

No PVE a média do DAP foi de $10,5 \mathrm{~cm}$, variando de 9,8 m (trat. 01 - clone G 0245) a 11,6 cm (trat. 04 - clone G 0256), não havendo porém diferenças estatísticas a $5 \%$ pelo teste TUKEY. A anälise ' de variância revelou um baixo coeficiente de variação $(5,64 \%)$ e o valor do teste $\mathrm{F}$ foi igual a 1,81 .

Na AQ a média do DAP foi de $8,4 \mathrm{~cm}$, variando de $7,7 \mathrm{~cm}$ (trat. 1 - clone G 0245) à 9,3 cm (trat. 15 - sementes de matri zes), não havendo porém diferenças estatísticas a $5 \%$ pelo teste TUKEY. A anālise de variância mostrou também baixo coeficiente de variação $(5,89 \%)$ e o valor do teste $\mathrm{F}$ igual a 2,83 . 
TABELA 4: Diāmetro à altura do peito (DAP-cm) aos 18 e 24 meses na Area Quartzosa e Podzö1ico Vermelho Es curo e a Anālise de Variância.

\begin{tabular}{|c|c|c|c|c|}
\hline \multirow[t]{3}{*}{ TRATAMENTO } & \multirow{2}{*}{\multicolumn{2}{|c|}{$\frac{\text { AREIA QUARTZOSA }}{\text { IDADE (MESES) }}$}} & \multirow{2}{*}{\multicolumn{2}{|c|}{$\frac{\text { PODZOLICO VERMELHO ESCURO }}{\text { IDADE (MESES) }}$}} \\
\hline & & & & \\
\hline & 18 & 24 & 18 & 24 \\
\hline 01 - Clone G-0245 & $7,3-\mathrm{CD}$ & $9,8-\mathrm{A}$ & $7,7-B$ & $20,4-E$ \\
\hline 02 - Clone G-0246 & $7,3-C D$ & $10,1-\mathrm{A}$ & $8,2-A B$ & $25,8-\mathrm{BCDE}$ \\
\hline 03 - Clone G-0269 & $8,4-A B C$ & $11,1-\mathrm{A}$ & $9,0-A B$ & $33,8-\mathrm{ABC}$ \\
\hline 04 - Clone G-0250 & $8,6-A B$ & $11,6-\mathrm{A}$ & $8,9-A B$ & $33,4-\mathrm{ABCD}$ \\
\hline 05 - Clone G-0256 & $7,0-D$ & $10,3-\mathrm{A}$ & $8,0-A B$ & $21,4-E$ \\
\hline 06 - Clone G-0258 & $7,6-\mathrm{ABCD}$ & $10,4-\mathrm{A}$ & $8,1-A B$ & $22,8-\operatorname{CDE}$ \\
\hline 07 - Clone G-0261 & $7,3-C D$ & $10,3-A$ & $7,9-A B$ & $20,1-\mathrm{DE}$ \\
\hline 08 - Clone G-0251 & $7,4-\mathrm{BCD}$ & $10,0-\mathrm{A}$ & $8,1-A B$ & $21,0-\mathrm{DE}$ \\
\hline 09 - Multiclones & $7,7-\mathrm{ABCD}$ & $10,3-\mathrm{A}$ & $8,4-\mathrm{AB}$ & $30,8-\mathrm{ABCDE}$ \\
\hline 10 - Multiclones & $7,6-\mathrm{ABCD}$ & $10,3-\mathrm{A}$ & $7,9-\mathrm{AB}$ & $28,3-\mathrm{CDE}$ \\
\hline 11 - Multiclones & $7,7-A B C D$ & $10,2-\mathrm{A}$ & $8,1-A B$ & $25,4-\mathrm{BCDE}$ \\
\hline 12 - Sem. Pomar Clona 1 & $8,4-\mathrm{ABC}$ & $10,9-A$ & $8,6-A B$ & $40,7-A B C D$ \\
\hline 13 - Sem. Pomar Clona1 & $8,6-A$ & $11,1-A$ & $8,9-A B$ & $43,4-\mathrm{AB}$ \\
\hline 14 - Sementes Matrizes & $8,3-\mathrm{ABC}$ & $10,7-\mathrm{A}$ & $8,8-A B$ & $36,5-\mathrm{ABC}$ \\
\hline 15 - Sementes Matrizes & $8,4-A B C$ & $10,8-A$ & $9,3-A$ & $42,2-A$ \\
\hline 16 - Semente Comercial & $8,7-A B C D$ & $10,4-\mathrm{A}$ & $8,8-A$ & $38,8-A B C$ \\
\hline Valor de $F$ & 5,24 & 1,81 & 2,83 & 7,61 \\
\hline Coef. de Variação & $5,17 \%$ & $5,64 \%$ & $5,89 \%$ & $6,17 \%$ \\
\hline
\end{tabular}

TRATAMENTOS COM LETRAS NÃO COMUNS DIFEREM A 5\% PELO TESTE TUKEY. 
50.

No Gräfico 3, observa-se a similaridade do DAP en tre os diferentes materiais testados.

No $\mathrm{P}$ V E as parcelas de sementes de pomar clonal, proporcionaram um crescimento às ärvores de $11,0 \mathrm{~cm}$, as de sementes de matrizes $10,8 \mathrm{~cm}$, as de sementes comerciais $10,4 \mathrm{~cm}$, os multiclones 10,3 $\mathrm{cm}$, os monoclones $10,4 \mathrm{~cm}$ e o melhor clone $11,0 \mathrm{~cm}$.

Na $A Q$ as parcelas de sementes de P.S. clonal apre sentaram média de DAP de $8,8 \mathrm{~cm}$, as de multiclones $8,1 \mathrm{~cm}$, as de monoclo nes $8,2 \mathrm{~cm}$ e a do melhor clone $9,9 \mathrm{~cm}$.

0 baixo coeficiente de variação encontrado na anā lise de variãncia mostra que existe bastante homogeneidade entre as ärvo res dentro de cada ensaio.

$\mathrm{Na}$ avaliação do volume de madeira produzida aos dois anos de idade, a Tabela 5 mostra que todos os tratamentos em estudo apresentaram desempenhos bem superiores quando plantados em Podzölico Vermelho Escuro (PVE), em média $57,3 \mathrm{~m}^{3} / \mathrm{ha}$ a mais em relação a Areia Quartzosa ( $\mathrm{AQ})$. A superioridade de um tratamento para outro seguiu prati camente a mesma proporção nos dois solos, não havendo, porém, diferen ças estatísticas ao nivel de $5 \%$ pelo teste TUKEY. 
A anālise de variância revelou um valor baixo do coeficiente de variação $(9,29 \%)$ e o valor de $F$ igual a 6,57 .

No PVE houve variação em produtividade desde 96,10 $\mathrm{m}^{3}$ /ha (trat. 1 - clone G 0245) atē $152,91 \mathrm{~m}^{3}$ /ha (trat. 15 - Pomar de se mentes clonal).

Na AQ o tratamento 7 foi considerado o pior (clone G 0261) com $54,37 \mathrm{~m}^{3} / \mathrm{ha}$, sendo o tratamento 13 (P.S. clona1) considerado o melhor, com $87,88 \mathrm{~m}^{3} /$ ha. O coeficiente de variação na análise de variāncia foi $14,22 \%$ e o valor de $F$ igual a 3,54.

Os tratamentos 3 e 7, cujas ärvores foram selecio nadas em Latossolo, não mostraram evidēncias em superar os demais, mesmo sendo plantados em solo com melhor fertilidade (PVE).

Talvez isso se justifique pelo fato de que quimicamente o Latossolo em questão apresenta baixos níveis de nutrientes, pois mesmo possuindo características químicas melhores que a Areia Quart zosa, hä sempre um gradiente de fertilidade dentro de um mesmo solo.

Este fato mostra tambëm a necessidade de melhores estudos visando analisar as interações que ocorrem com o material genē 
GRÁFICO 3: Diâmetro médio a altura do peito (DAP) das ärvores (cm) para os diferentes materiais genéticos, aos dois anos de ida nos dois locais.

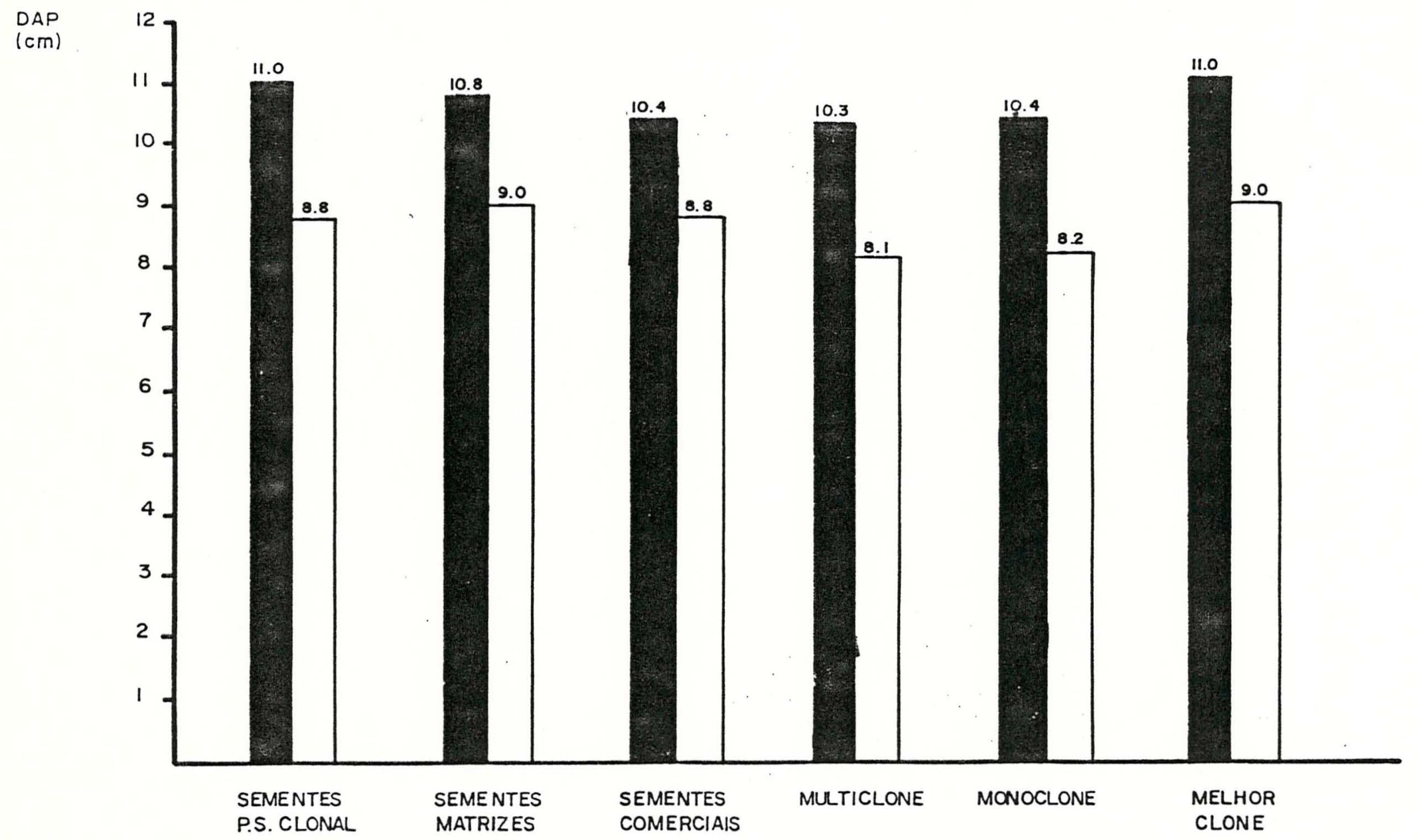


TABELA 5: Volume cilfndrico $\left(\mathrm{m}^{3} / \mathrm{ha}\right)$ aos 18 e 24 meses nos dois locais e os resultados da Anä1ise de Variāncia.

\begin{tabular}{|c|c|c|c|c|}
\hline \multirow{2}{*}{ TRATAMENTO } & \multicolumn{2}{|c|}{$\frac{\text { PODZOLICO VERMELHO ESCURO }}{\text { IDADE (MESES) }}$} & \multicolumn{2}{|c|}{$\frac{\text { AREIA QUARTZOSA }}{\text { IDADE (MESES) }}$} \\
\hline & 18 & 24 & 18 & 24 \\
\hline 01 - Matriz G-0245 & $35,87-F$ & $96,10-D$ & $20,38-E$ & $59,65-A B$ \\
\hline 02 - Matriz G-0246 & $38,25-\mathrm{EF}$ & $105,80-C D$ & $25,81-\mathrm{CDE}$ & $62,94-A B$ \\
\hline 03 - Matriz G-0269 & $.61,18-A B C$ & $147,07-\mathrm{AB}$ & $33,81-A B C D$ & $72,67-A B$ \\
\hline 04 - Matriz G-0250 & $53,07-\mathrm{BCDE}$ & $133,79-\mathrm{ABC}$ & $33,35-\mathrm{ABCD}$ & $76,57-A B$ \\
\hline 05 - Matriz G-0256 & $35,44-F$ & $112,80-\mathrm{BCD}$ & $21,41-D E$ & $61,30-A B$ \\
\hline 06 - Matriz G-0258 & $43,18-D E F$ & $112,29-\mathrm{BCD}$ & $22,78-D E$ & $57,70-B$ \\
\hline 07 - Matriz G-0261 & $37,75-E F$ & $109,21-C D$ & $20,09-E$ & $54,37-B$ \\
\hline 08 - Matriz G-0251 & $40,92-E F$ & $105,80-C D$ & $20,98-D E$ & $58,53-A B$ \\
\hline 09 - Multiclones & $47,80-\mathrm{CDEF}$ & $121,13-A B C D$ & $30,82-A B C D E$ & $68,10-A B$ \\
\hline 10 - Multiclones & $45,46-\mathrm{DEF}$ & $121,56-\mathrm{ABCD}$ & $28,30-\mathrm{BCDE}$ & $64,36-A B$ \\
\hline 11 - Multiclones & $53,00-B C D E$ & $131,78-A B C D$ & $25,44-\mathrm{CDE}$ & $59,79-\mathrm{AB}$ \\
\hline 12 - Sem. Pomar clonal & $64,24-A B$ & $145,27-A B$ & $40,68-A B$ & $78,94-\mathrm{AB}$ \\
\hline 13 - Sem.Pomar clonal & $68,94-A$ & $147,06-A B$ & $43,39-A$ & $87,88-A$ \\
\hline 14 - Sementes Matrizes & $61,48-A B C$ & $138,05-A B C$ & $36,48-A B C$ & $75,79-\mathrm{AB}$ \\
\hline 15 - Sementes Matrizes & $67,05-A B$ & $152,91-A B$ & $42,19-A$ & $87,85-A$ \\
\hline 16 - Sementes Comerciais & $56,86-A B C D$ & $140,00-A B C$ & $38,81-A B$ & $77,03-\mathrm{AB}$ \\
\hline Valor de $F$ & $14,25 * *$ & $6,57 * *$ & $10,97 * *$ & $3,54 * *$ \\
\hline Coef. de Variação & $10,16 \%$ & $9,29 \%$ & $13,99 \%$ & $14,22 \%$ \\
\hline
\end{tabular}

TRATAMENTOS COM LETRAS NÃO COMUNS DIFEREM ESTATISTICAMENTE A 5\% PELO TESTE TUKEY

** Significativo a $1 \%$ pelo teste F. 
tico quando plantado em situação diferente daquela onde foi selecionado.

$\mathrm{Na} A Q$ a anälise de variāncia mostrou coeficiente de variação, igual a $14,22 \%$ e o valor do teste $F$ igual a 3,54 .

$$
4.1 .4-\underline{\text { Volume }}
$$

Analisando no Gräfico 4 o comportamento silvicultural dos diferentes materiais em função da melhoria genética, observa se que no PVE os melhores tratamentos foram as parcelas do clone G 0269 , $\operatorname{com} 147,0 \mathrm{~m}^{3} / \mathrm{ha}$, seguido das sementes de pomar clonal $\left(146,2 \mathrm{~m}^{3} / \mathrm{ha}\right)$, das sementes das matrizes $\left(145,5 \mathrm{~m}^{3} / \mathrm{ha}\right)$ e das sementes comerciais $\left(140,0 \mathrm{~m}^{3} /\right.$ ha). Não houve porém, diferenças estatísticas entre eles ao nível de $5 \%$ pelo teste TUKEY.

Segundo KAGEYAMA (1980), o ganho genëtico teörico esperado para volumede E.grandis quando se compara sementes comerciais e sementes de matrizes ë em torno de 13,5\%. Entre as sementes comerciais e as obtidas em pomar clonal o ganho teórico se eleva para aproximadamente $27 \%$. Para esses cálculos tem-se empregado coeficiente de variação feno típico $(\mathrm{CVF})=52 \%$, herdabilidade $\left(\mathrm{h}^{2}\right)=0,20$ e intensidade de seleção, (i) $=2,6$. 
GRAFICO 4: Volume cilindrico mëdio $\left(\mathrm{m}^{3} / \mathrm{ha}\right)$ dos diferentes materiais genéticos, aos dois anos de idade, nos dois locais.

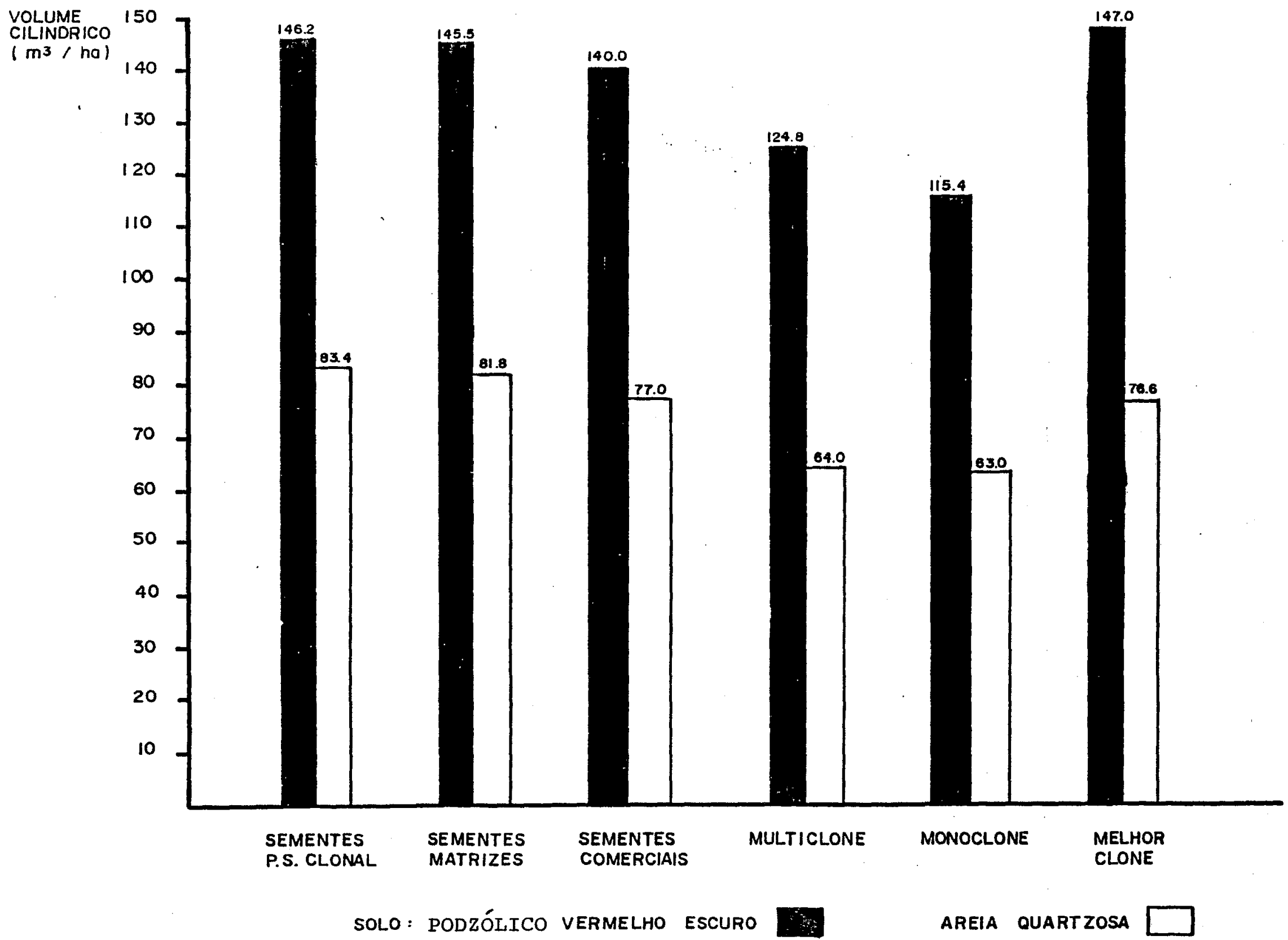


56.

No PVE as estimativas de ganhos reais encontrados

foram:

a) do pomar clonal em relação às sementes comer ciais: $+4,4 \%$.

b) das sementes das matrizes em relação as sementes comerciais: $+3,9 \%$.

Observa-se que as estimativas dos ganhos reais ob tidos nos itens a e $\underline{b}$ são bem inferiores aos ganhos teóricos estimados' por KAGEYAMA (1980), evidenciando que a seleção das ärvores realizada em sitios com características diferentes aos sítios onde foram plantadas ( Fazenda Piracema e Talhão 280 da Fazenda Rio Claro em Lençóis Paulista SP) foi um fator que deve ter influenciado no desenvolvimento das ärvo res, ou seja, a interação genōtipo $x$ ambiente manifestou-se com grande evidência.

MORI et alii (1986) demonstraram em um estudo sobre interação genótipo $x$ ambiente com progēnies de Eucalyptus saligna , instalado em 3 localidades distintas: Bom Despacho - MG; Brotas - SP e General Câmara - RS, as perdas no progresso genético esperado. Este ga nho foi reduzido a $83,3 \%$ quando o material foi selecionado para volume cilindrico em Bom Despacho - MG e utilizado para o plantio em Brotas-SP. 
Na AQ a estimativa de ganho real obtido pelas plantas produzidas por sementes de matrizes em relação às de sementes co merciais foi de $8.3 \%$, contra $27 \%$ na estimativa teórica.

Neste caso ( $\mathrm{AQ}$ ) houve tambëm influēncia do ambien te no comportamento fenotipico dos materiais testados, confirmando a importāncia da interação GENÓTIPO x AMBIENTE encontrada por diversos autores em outras situações: VENCOVSKY (1978), KAGEYAMA (1980), MORGENSTERN( 1982), ZOBEC e TALBERT (1984), PATIÑO-VALERA (1986), MORI et alii (1986), dentre outros.

Isto mostra a necessidade da instalação de testes clonais em diferentes sitios, visando avaliar a potencialidade silvicultural de cada material genético para cada situação, utilizando racionalmente a interação.

A anälise conjunta dos dois ensaios revelou coefi ciente de variação, muito alto apenas para a porcentagem de falhas $(83,1 \%)$ indicando que apesar de não haver diferenças estatisticas a $5 \%$ de significāncia no teste TUKEY, as parcelas são bastante heterogēneas. Para a característica altura o coeficiente de variação foi de 5,36\%, para DAP $5,78 \%$ e para volume $11,07 \%$.

Os valores de $F$ para falhas foi 2,67 , para altura 
11,84, para DAP 12,27 e para volume 24,46 .

No Gräfico 4, observa-se também que os tratamen tos propagados por sementes (comerciais, matrizes e de pomar) apresentaram um comportamento melhor que a média das parcelas de monoclones e tam bém dos multiclones. Uma hipótese que poderia justificar tal fato seria a arquitetura do sistema radicular das mudas produzidas por sementes, a qual possui características do tipo pivotante muito mais acentuada que as apresentadas pelas estacas.

Outra hipótese seria a da idade de avaliação

anos) ser bem inferior à idade mëdia em que foi feita a seleção ( 7 anos), pois a alta correlação encontrada por KAGEYAMA (1983) entre a seleção de ärvores aos 2 e aos 6 anos em E. grandis propagados por sementes pode ser diferente quando se tratar de clones.

No Gräfico 4, evidencia-se também a ocorrēncia de ligeiros aumentos no volume de madeira produzida pelas parcelas de multí clones em relação à média dos monoclones. No PVE a mëdia das três parcelas de multiclones foi de $124,8 \mathrm{~m}^{3} / \mathrm{ha}$ e a média das oito parcelas mono clonais foi de $115,4 \mathrm{~m}^{3} /$ ha, ou seja, diferença de $8,1 \%$.

$\mathrm{Na} A Q$ a média dos oito monoclones foi de $63,0 \mathrm{~m}^{3} /$ 
ha e das trës parcelas multiclonais foi de $64,0 \mathrm{~m}^{3} / \mathrm{ha}$, ou seja, diferença de 1,5\%. Tais resultados também foram encontrados por GUAZELLI (1982), SAKAY (1961), CARDOSO e VIEIRA (1972), ALLARD e ADAMS (1969), para outros materiais.

As estimativas de ganhos reais obtidos em volumes de madeira aos dois anos podem ser melhor comparados na Tabela 6 .

TABELA 6. Estimativas de ganhos reais obtidos pelos diferentes materiais aos dois anos em relação às sementes comerciais.

\begin{tabular}{lcc}
\hline & S 0 L 0 & \\
\cline { 2 - 3 } MATERIAL GENETICO & P V E & A Q \\
\hline P.S. CLONAL & $+4,4 \%$ & $+8,3 \%$ \\
SEMENTES DE MATRIZES & $+3,9 \%$ & $+6,2 \%$ \\
MULTICLONES & $-12,2 \%$ & $-20,3 \%$ \\
MONOCLONES & $-21,3 \%$ & $-22,2 \%$ \\
MELHOR CLONE (G 0269) & $+5,0 \%$ & $+0,5 \%$ \\
\hline
\end{tabular}

PVE = Podzólico Vermelho Escuro

$\mathrm{AQ}=$ Areia Quartzosa

4.2 - CONSIDERAÇÕES SOBRE O ASPECTO NUTRICIONAL 
Em função das anālises foliares de macro e micronutrientes, realizadas 12 meses após o plantio, e mostradas nas Tabelas: 7, 7A, 8 e $8 \mathrm{~A}$, pode-se observar o comportamento diferenciado dos trata mentos por sementes e estacas no PVE e AQ.

No PVE as ärvores oriundas de sementes de pomar ' clonal apresentaram concentrações inferiores de Nitrogênio, Potässio, Fōs foro e Magnēsio em relação aos melhores clones.

\begin{abstract}
Apesar dos resultados das anālises químicas mos trarem diferenças entre os materiais testados para os diversos nutrien tes, considera-se ainda bastante prematura e perigosa qualquer definição sobre a eficência nutricional dos materiais genéticos. No entanto, os re sultados mostram indicações muito importantes sobre as diferenças no com portamento dos diversos materiais genéticos com relação à capacidade de absorção nutricional.
\end{abstract}

A continuidade das anälises no futuro, bem como a instalação de novos ensaios a partir de resultados obtidos, são de extre ma relevância, pois o mesmo deu um enfoque bastante amplo no assunto, pro curando conhecer as interaçōes entre o genötipo com o clima e os solos' estudados. 
61.

0 mais importante, no entanto, foi que houve va riaçōes expressivas entre os materials genéticos para a análise follais de alguns elementos. Deve-se enfatizar tambëm, que o comportamento dos materiais genēticos não foi o mesmo para os diferentes elementos. Esse fato abre perspectivas muito interessantes para o aprofundamento dos estudos quanto à questão nutricional de progēnies clonais e por sementes. 
TABELA 7: Resultados da Anälise Fọliar após 12 meses do plantio, para macronutrientes no ensalo instalado em Arefa Quartzosa.

\begin{tabular}{|c|c|c|c|c|c|c|c|c|c|c|c|}
\hline \multicolumn{2}{|c|}{ NITROGENIO } & \multicolumn{2}{|c|}{ FÓSFORO } & \multicolumn{2}{|c|}{ POTÁSSIO } & \multicolumn{2}{|c|}{ CÁLCIO } & \multicolumn{2}{|c|}{ MAGNESIO } & \multicolumn{2}{|c|}{ ENXÔFRE } \\
\hline $\mathrm{T}(5 \%)$ & Trat. & $\%$ & Trat & $\%$ & Trat. & $\%$ & Trat. & $\%$ & Trat. & $\%$ & Trat. \\
\hline 2,1267 & PSC & $T^{0,1200}$ & GO256 & $T^{1,1733}$ & G0261 & $T^{0,44333}$ & PSC & $T^{0,22333}$ & G0245 & $T^{0,12000}$ & SAM \\
\hline 2,0033 & G0250 & 0,10667 & PSC & 1,0700 & G0246 & 0,40333 & SAM & 0,21667 & G0258 & 0,11000 & G0256 \\
\hline 1,9767 & SAC & 0,10000 & SAM & 1,0700 & G0256 & 0,39667 & SAC & 0,20667 & G0261 & 0,11000 & PSC \\
\hline 1,9333 & G0245 & 0,09667 & G0245 & 0,9700 & G0258 & 0,36000 & G0250 & 0,20000 & G0250 & 0,10667 & G0250 \\
\hline 1,9300 & SAM & 0,09333 & G0250 & $1_{0,8700}$ & SAM & 0,34667 & PM & 0,19000 & SAM & 0,10667 & FM \\
\hline 1,9300 & G0256 & 0,09333 & G0258 & 0,8433 & G0250 & 0,34000 & G0245 & 0,18333 & PSC & 0,10333 & G0245 \\
\hline 1,8267 & G0269 & 0,09000 & G0261 & 0,8200 & G0269 & 0,32000 & G0256 & 0,17000 & G0256 & 0,10333 & G0258 \\
\hline 1,8067 & PM & $I_{0}, 09000$ & SAC & 0,8200 & PM & 0,32000 & G0261 & $L_{0,17000}$ & SAC & 0,9667 & G0269 \\
\hline $1,7,433$ & G0261 & 0,08333 & PM & 0,7933 & PSC & 0,31333 & G0258 & 0,15000 & G0246 & 0,09000 & SAC \\
\hline 1,7300 & G0258 & 0,07333 & G0269 & 0,7933 & SAC & 0,29667 & G0269 & 0,15000 & PM & 0,08333 & G0261 \\
\hline $1,7.133$ & G0246 & 0,07333 & G0246 & 0,7933 & G0245 & $I_{0,28000}$ & G0246 & 10,15000 & G0269 & 0,08333 & G0251 \\
\hline 1,6033 & G0251 & 10,07000 & G0251 & 0,7667 & G0251 & $I_{0,24333}$ & G0251 & 10,12333 & G0251 & $I_{0,08333}$ & G0246 \\
\hline$F=1,97$ & n.s. & 5,36 & $* *$ & 5,03 & $* \dot{*}$ & 3,03 & $*$ & 5,22 & $* *$ & 1,26 & n.s. \\
\hline $\begin{array}{r}\mathrm{C} . \mathrm{V}_{.}= \\
9,84\end{array}$ & - & 12,00 & - & 11,76 & - & 16,50 & - & 13,17 & - & 18,95 & - \\
\hline
\end{tabular}

$T=$ TESTE TUKEY

SAM $=$ SEMENTES DE ARVORES MATRIZES

PSC $=$ SEMENTES DE POMAR CLONAL

SC = SEMENTES COMERCIAIS

PM = PARCELAS MULTICLONAIS
* Significativo ao nível de $5 \%$ pelo teste F

* Significativo ao nível de $1 \%$ pelo teste F. 
TABELA 7A: Resultados da Anälise Foliar apös 12 meses do plantio para micronutrientes no ensaio instalado em Arela Quartzosa.

\begin{tabular}{|c|c|c|c|c|c|c|c|c|c|}
\hline \multicolumn{2}{|l|}{ FERRO } & \multicolumn{2}{|c|}{ COBRE } & \multicolumn{2}{|c|}{ BORO } & \multicolumn{2}{|c|}{ ZINCO } & \multicolumn{2}{|c|}{ MANGANES } \\
\hline $\mathrm{T}$ (5\%) $\mathrm{ppm}$ & Trat. & ppm & Trat. & $\mathrm{ppm}$ & Trat. & ppm & Trat. & $\mathrm{ppm}$ & Trat. \\
\hline$T^{192,00}$ & G0245 & $T^{6,3333}$ & PSC & $T^{54,333}$ & PSC & $T^{14,00}$ & SAM & 444,33 & G0261 \\
\hline T 179,67 & SAC & 6,0000 & G0250 & 39,667 & G0251 & 13,333 & G0256 & 437,00 & PSC \\
\hline 174,33 & SAM & 6,0000 & G0246 & 36,667 & SAM & 13,333 & G0258 & 424,33 & PM \\
\hline 163,33 & PSC & 5,6667 & G0256 & 36,000 & G0245 & 13,333 & G0261 & 417,00 & G0245 \\
\hline 160,33 & PM & 5,6667 & SAM & 36,000 & G0258 & 12,667 & 60245 & 412,00 & G0246 \\
\hline 1145,00 & G0246 & 5,0000 & G0258 & 32,667 & G0256 & 12,333 & PM & 410,33 & G0250 \\
\hline 139,33 & G0251 & 5,0000 & PM & 30,000 & PM & 12,000 & PSC & 409,33 & SAC \\
\hline 133,33 & G0261 & 5,0000 & $\mathrm{SAC}$ & 29,333 & G0250 & 12,000 & SAC & 408,33 & G0258 \\
\hline $1 \quad 132,00$ & G0269 & 4,6667 & G0245 & 27,333 & G0269 & 10,667 & G0250 & 398,67 & SAM \\
\hline 129,00 & G0258 & 4,3333 & G0261 & 27,000 & G0246 & 9,667 & G0269 & 395,33 & G0251 \\
\hline 124,67 & G0256 & 4,0000 & G0269 & 23,667 & G0261 & 9,667 & G0251 & 381,00 & G0256 \\
\hline $1 \quad 124,00$ & G0250 & 12,6667 & G0251 & 123,000 & SAC & 9,667 & G0246 & 365,33 & G0269 \\
\hline$F=5,70$ & $* *$ & 1,54 & n.s. & 1,37 & n.s. & 4,11 & $* *$ & 1,60 & n.s: \\
\hline C.v. $=11,33$ & - & 28,53 & - & 38,42 & - & 11,43 & - & 7,38 & - \\
\hline
\end{tabular}

$\mathrm{T}=$ TESTE TUKEY

SAM = SEMENTES DE ARVORES MATRIZES

PSC $=$ SEMENTES DE POMAR CLONAL

$S C=$ SEMENTES COMERCIAIS

PM = PARCELAS MULTICLONAIS
* Significativo a $5 \%$ pelo teste F

** Significativo a $1 \%$ pelo teste F. 
TABELA 8: Resultados de Anālise Foliar após 12 meses do plantio, para macronutrientes no ensaio instalado em Podzölicọ Vermelho Escuro.

\begin{tabular}{|c|c|c|c|c|c|c|c|c|c|c|c|}
\hline \multicolumn{2}{|c|}{ NITROGENIO } & \multicolumn{2}{|c|}{ FÓSFORO } & \multicolumn{2}{|c|}{ POTÁSSIO } & \multicolumn{2}{|c|}{ CÁLCIO } & \multicolumn{2}{|c|}{ MAGNESIO } & \multicolumn{2}{|c|}{ ENXOFRE } \\
\hline T (5\%) \% & Trat. & $\%$ & Trat. & $\%$ & Trat. & $\%$ & Trat. & $\%$ & Trat. & $\%$ & Trat. \\
\hline$T^{2,7467}$ & G0246 & $T^{0,13667}$ & G0261 & $T^{1,1233}$ & G0269 & $T^{0,69000}$ & PSC & $T^{0,31333}$ & G0250 & $T^{0,12667}$ & G0261 \\
\hline 2,5567 & G0250 & 0,12667 & SAC & 1,1200 & G0246 & 0,68667 & G0250 & 0,30667 & G0269 & 0,11667 & PM \\
\hline 2,4133 & SAM & 0,12667 & G0256 & 1,0200 & G0250 & 0,65333 & SAC & 0,30667 & G0261 & 0,11667 & SAC \\
\hline 2,3033 & G0269 & 0,12667 & SAM & 1,0200 & G0256 & 0,63333 & G0261 & 0,28667 & SAC & 0,11333 & G0250 \\
\hline 2,2767 & G0261 & 0,12333 & G0246 & 0,9933 & G0261 & 0,63333 & G0269 & 0,28000 & SAM & 0,11333 & SAM \\
\hline 2,2767 & G0258 & 0,12333 & G0250 & 0,9700 & $\mathrm{PM}$ & 0,59667 & SAM & 0,28000 & G0258 & 0,10667 & PSC \\
\hline 2,1600 & PSC & 0,12000 & G0269 & 0,9700 & G0251 & 0,57000 & PM & 0,27000 & 60245 & 0,10667 & G0251 \\
\hline 2,1300 & G0251 & 0,12000 & PM & 0,9700 & SAC & 0,52333 & G0258 & 0,27000 & PM & 0,10333 & G0246 \\
\hline 2,1133 & PM & 0,11667 & G0251 & 0,9433 & G0245 & 0,50000 & G0245 & 0,27000 & PSC & 0,10000 & G0245 \\
\hline 2,0867 & G0256 & 0,11333 & G0245 & 0,9200 & SAM & $I_{0,48333}$ & G0246 & 0,25333 & G0246 & 0,09667 & G0269 \\
\hline $\mathrm{I}_{2,0500}$ & SAC & 0,11333 & G0258 & 0,8933 & PSC & 0,43000 & G0251 & $I_{0,23667}$ & G0256 & 0,09333 & G0258 \\
\hline 11,4533 & G0245 & $I_{0,10667}$ & PSC & $I_{0,8700}$ & G0258 & 0,42333 & G0256 & 0,21333 & G0251 & $I_{0,09000}$ & G0256 \\
\hline $\mathrm{F}=1,60$ & n.s. & 0,72 & n.s. & 1,8 & n.s. & 3,86 & $* *$ & 2,39 & $*_{=}$ & 1,59 & n.s. \\
\hline $\begin{array}{l}\text { C.v. }= \\
19,53\end{array}$ & - & 13,40 & - & 13,34 & - & 14,74 & - & 12,00 & - & 13,97 & - \\
\hline
\end{tabular}

$\mathrm{T} \quad=$ TESTE TUKEY

SAM = SEMENTES DE ARVORES MATRIZES

PSC $=$ SEMENTES DE POMAR CLONAL

$\mathrm{SC}=$ SEMENTES COMERCIAIS

PM = PARCELAS MULTICLONAIS

* Significativo a 5\% pelo teste F

** Significativo a $1 \%$ pelo teste F. 
TABELA 8A: Resultados de Análise Foliar após 12 meses do plantio, para micronutrientes no ensiao 1nstalado em Podzölico Vermelho Escuro.

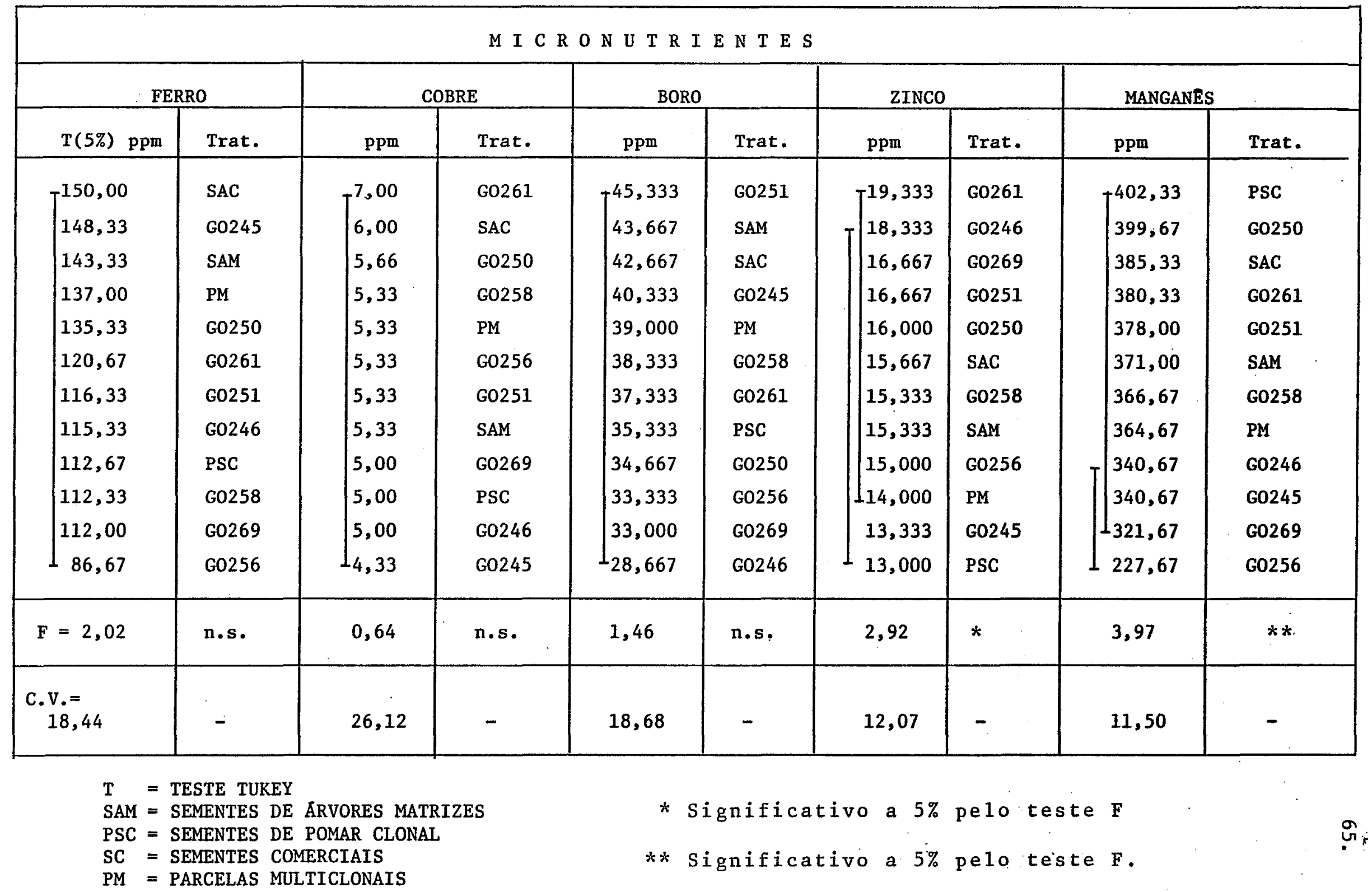


66.

5. CONCLUSÕES

a) A produtividade média no solo Podzólico Vermelho Escuro (PVE) $126,29 \mathrm{~m}^{3}$ sólidos/ha foi $57,32 \mathrm{~m}^{3} /$ ha superior (83\%) à media de pro dutividade da Areia Quartzosa (AQ) - 68,97 $\mathrm{m}^{3} / \mathrm{ha}$.

b) Os materiais propagados via semente apresentaram melhores resultados para pomar clonal, vindo a seguir as sementes de matrizes e por ultimo as sementes comerciais. 0 material propagado por esta quia não correspondeu à expectativa teórica.

c) As parcelas multiclonais apresentaram desenvolvimento superior às parcelas monoclonais, principalmente no PVE, onde a superioridade, foi de $8,1 \%$ em volume.

d) Houve variação genética entre clones nos dois solos testados. 
e) A interação dos diferentes materiais genéticos com os dois solos mostrou-se pouco expressiva, com comportamento semelhante dos mesmos nos dois solos.

f) As estimativas de ganhos genëticos reais foram inferiores às teori camente esperadas.

g) Os materiais genéticos mostraram variações nas concentrações de nụ trientes em suas folhas. 
68.

6. LITERATURA CITADA

ALLARD, R.W. e ADAMS, J., 1969. Population studies in predominanty self pollinated species. XIII - Intergenotypic competiton and population structure in Barley and wiheat. The Amer.Not. 103:621-644.

BALLONI, E.A. et alii, 1978. Fertilização Floresta1 - IPEF - Boletim Informativo, Piracicaba - SP, 6(16): A-1-34.

BALLONI, E.A., 1979. 0 uso intensivo da floresta e seus reflexos na fer tilidade do solo. IPEF - Circular Tëcnica, Piracicaba, (45): 1-17.

BALLONI, E.A. et alii, 1980. O espaçamento de plantio e suas implicações silviculturais - IPEF - Série Técnica, Piracicaba, 1 (3): 1-16.

BARNES, R.D., 1983. Variation and genotype: environment interaction in international provenance trials of Pinus Caribaea and implications for population improvement strategy. Silvicultura, São Paulo, 8(29) : $35-42$. 
69.

BARROS, N.F. de, 1980. Algumas considerações sobre relaciones entre si tio y suelo. In IUFRO/MAB - USDA - Producion de madera em 1os. Ne Tro picos via plantaciones. Rio Piechas, Instituto de Dazonomia Tropical, 420 p.

BARROS, N. F. de, 1986. A interação genōtipo - solo em espécies flores tais. Seminärio sobre interação do genötipo com o clima e solo. Piracicaba - SP, IPEF/ESALQ, p. 11-3.

BELL, H.E. et alii, 1979. Family x Fertilizer interaction in one year old Douglas - Fir. Silva Genetica, 28(1): 1-5.

BELLOTE, A. F. J. et alii, 1980. Extração e exportação de nutrientes pelo Eucalyptus grandis Hill ex Maiden em função da idade. IPEF - Piracicaba - SP., (20): 1-23.

CARDOSO, A.A. et alii, 1972. Progressos nos Estados Unidos sobre mistu ras varietais de feijão, Phaseolus vulgaris L. ceres Viçosa, 100:465477.

CARMEAN, W.H., 1979. Site index comparisons among northem hardwoods in northem Wisconsin and Upper Michigan. USDA. Forest Service NC research paper, St. Paul, (169): 1-17 
70.

DANIELS, J.D., 1984. Rode of tree improvement in intensive forest mariagement. Forest Ecology and Management. Amsterdam, $\underline{8}$ (3/4): 161-165.

EMBRAPA - Empresa Brasileira de Pesquisa Agropecuäria, 1978. Centro de Pesquisa Agropecuäria dos Cerrados, Planaltina - DF. Relatório Técnico Anual - 1976 a 1977,183 p.

FONSECA, S.M. da, 1979. Estimação e interpretação dos componentes da variação total em experimentos de melhoramento florestal. Curso sobre "Prāticas Experimentais em Silvicultura". Piracicaba - SP, 1-20

GENYS, J.B., 1980. Variation of clonal progennies from Pinus in the Nor theastern United States grown in Manyland's nursey. Silvae genética, Frankfurt, 23(4):99-104.

GESSEL, S.P., 1982. Site evaluation in forest production and management. Reunion de Trabajo in Manejo Forestal. Valdivia, p. 326-57.

GIBSON, G.L., 1982. Genotype enviromment interation in Pinus caribaca Oxford, commanwealt Forestry Institute. 124 pp.

GODDARD, R.E., 1977. Cooperative forest genetics research programs. s.I. p., University Florida. 16 p. 
GOMES, S.L., 1985. Correlaçōes das características físicas e químicas dos solos com a produtividade florestal. Plano de Projeto da DURAFLORA Silvicultura e Comërcio Ltda. Jundiaí, SP, p. 1-16.

GUAZELLI, R.J., 1975. Competição intergenotípica em feijão (Phaseolus vul garis L.) = Estimação da capacidade competitiva. Piracicaba, ESALQ USP. $60 \mathrm{p}$.

HAAG, H. P. et alii, 1983. Variação de florestas implantadas de Eucalyptus e Pinus sobre as propriedades químicas do solo. Silvicultura, São Paulo $8(32): 643-5$

JAHROMI, S.T.; GODDARD, R.E. \& SMITH, W.H., 1976. Genotype fertilizer interactions in slash pine: growth and nutrient relations. Forest science, Washington, 22(2): 211-9, junho.

JONES, et alii, 1975. Height growth comparation of some quaking aspen clones in Arizona - USDA - for Serv. R.M. research note. Fort. Collins, $(282): 1-4$

KAGEYAMA, P.Y., 1980. Variação genētica em progenies de uma população de Eucalyptus grandis (Hil1) ex. Maiden. Piracicaba, ESALQ - USP. 71 p. (Tese de Mestrado). 
KAGEYAMA, P.Y., 1986. Interação de genötipos por ambientes. Piracicaba SP, IPEF/ESALQ. Seminärio sobre interação do genōtipo com clima e so1o, p. $18-20$.

MORGENSTERN, E.K., 1982. Interactions between genotype site and silvicu1 tural treatment. Informations report PI - Y. CHARLK - River, (14): 118.

MORI, E.S. et alii, 1986. Interação genötipo x clima e solo. Revisão Bibliográfica para o Seminärio sobre interação do genötipo com clima e solo. IPEF/ESALQ, Piracicaba - SP, p. 1-7.

NAMKOONG, G. et alii, 1980. A phylosophy of beeding strategy for tropical forest trees. Commanucalth Foresty Institute. University of Oxford . 67 pp.

PATIÑO-VALERA, F.P., 1986. Variação genētica em progēnies de Eucalyptus saligna. Smith e sua interação com o espaçamento. Universidade de São Paulo, ESALQ, Piracicaba - SP. 192 pp. (Tese de Mestrado).

QUIJADA, M. et alii, 1976. Sobreviẽncia y crescimento en altura a los quatro años de precedência de Pinus ellcotri y Pinus taeda, plantados en la Mucuy, E do Merida, Venezuela. Revista florestal Venezoelana, Merida, (26): 45-59. 
RALSTON, C.W. et alii, 1980. Identification of lower coastal plain sites of low soil fertility. Southern Journal of applied forestry. Washington, $4(2): 84-8$.

RANZANI, G. 1962. Pequeno guia para levantamento de solos. Piracicaba, ESALQ s.d. 34 p.

SHELBOURNE, G.J.A., 1972. Genotype enviroment interaction: its study and its implications in florest tree improvement. IUFRO Genetcs sabaojoint Symposio TOKIO, 28 pp.

SCHLATTER, J. E., 1983. E1 sítio, concepto fundamental de la actividad forestal. Chile forestal, Santiago, 8(92), 19-9.

SANCHES-MEJORADA, K. et alii, 1986. The ninth worldforestry congress: a report. Unasylva, Roma, 38(151): 34-9, mar.

SQUILACE, A.E., 1969. Genotype enviroment interactions in forest tress. Second meeting of the group on quantitative Genetics. IUFRo. Section 22. USDA. Fores't Serv. Southern. Forest, p. 49-61.

VENCOVSKY, R., 1978. Herança quantitativa In: PATERNIAMI, E. Melhoramen to de Milho no Brasil. Piracicaba, Fundação Cargill. p. 122-129. 
74.

WELLS, 0.0. et alii, 1982. Genotype - environment interaction in rust re sistence in Mississipi lablolly pine. Forest Science, Washington, 28 (4): 797-809.

ZOBEL, B., et alii, 1984. Applied Forest tree improvement. New York, John Wiley e Sons. 505 p. 
7.5

7. A P E N D I C E 
TABELA 9: Informaçōes gerais sobre as sementes utilizadas nos ensaios.

\begin{tabular}{|c|c|c|c|c|c|c|c|c|c|c|}
\hline № DO TRATAMENTO & 1 & 2 & 3 & 4 & 5 & 6 & 7 & 8 & 12 e 13 & 16 \\
\hline № DA MATRIZ SELECIONADA & G-0245 & G-0246 & G-0269 & G-0250 & G-0256 & G-0258 & G-0261 & G-0251 & PSC & $\begin{array}{c}\text { SEMENTE } \\
\text { COMERCIAI }\end{array}$ \\
\hline QUADRA - PROJETO & $179-D$ & $179-D$ & $260-E$ & $180-D$ & $182-\mathrm{D}$ & 183-D & $174-D$ & $182-D$ & & $231-E$ \\
\hline ESPECIE & E Grandis & E.Grandis & E.Grandis & E.Grandis & E Grandis & E.Grandis & E.Grandis & E.Grandis & E.Gradis & E.Grandis \\
\hline PROCEDENCIA & Natal & Natal & Natal & Natal & Natal & Natal & Natal & Natal & $\mid \begin{array}{c}\text { Cuff's } \\
\text { Harbour }\end{array}$ & Natal \\
\hline ESPACAMENTO (M) & $3,0 \times 1,5$ & $3,0 \times 1,5$ & $3,0 \times 1,5$ & $3,0 \times 1,5$ & $3,0 \times 1,5$ & $3,0 \times 1,5$ & $3,0 \times 1,5$ & $3,0 \times 1,5$ & & $3,0 \times 1,5$ \\
\hline AREA DA QUADRA (ha) & 46,23 & 46,23 & 19,45 & 33,65 & 16,52 & 36,77 & 24,72 & 16,52 & & 27,19 \\
\hline DATA DE PLANTIO (MES/ANO) & $12 / 74$ & $12 / 74$ & $02 / 76$ & $12 / 74$ & $12 / 74$ & $12 / 74$ & $10 / 74$ & $12 / 74$ & & $01 / 76$ \\
\hline DATA DE CORTE (MES/ANO) & $09 / 82$ & $09 / 82$ & $01 / 83$ & $09 / 82$ & $09 / 82$ & $09 / 82$ & $02 / 83$ & $09 / 82$ & - & $06 / 82$ \\
\hline IDADE (ANOS, MESES) & 7,9 & 7,9 & 6,11 & 7,9 & 7,9 & 7,9 & 8,4 & 7,9 & & 6,5 \\
\hline ALTURA MÉDIA - QUADRA (M) & 18,6 & 18,6 & 22,3 & 17,5 & 20,1 & 23,0 & 21,2 & 20,1 & 12,0 & 22,9 \\
\hline DAP MÉDIO - QUADRA (CM) & 12,2 & 12,2 & 13,1 & 11,5 & 13,0 & 15,1 & 14,2 & 13,0 & - & 16,6 \\
\hline FALHAS - QUADRA (\%) & 13,9 & 13,9 & 3,8 & 15,3 & 15,9 & 21,0 & 24,2 & 15,9 & 10,0 & 12,6 \\
\hline PRODUTIVIDADE - IMA (STCC/ha/DME) & 49,6 & 49,6 & 98,2 & 44,7 & 56,6 & 73,4 & 57,5 & 56,6 & - & 79,9 \\
\hline MEDIA DE CASCA $(\%)$ & 12,5 & 12,5 & 11,9 & 12,7 & $1 \dot{2}, 2$ & 11,9 & 12,1 & 12,2 & - & 12,4 \\
\hline № DE FUSTES PARA FORMAR 1 ESTEREO & 5,3 & 5,3 & 3,0 & 3,3 & 3,7 & 3,3 & 3,8 & 3,7 & - & 4,1 \\
\hline FATOR DE EMPILHAMENTO & 1,74 & 1,74 . & 1,72 & 1,75 & 1,71 & 1,70 & 1,71 & 1,71 & - & 1,72 \\
\hline ALTURA DA ARVORE MATRIZ (M) & 28,0 & 29,2 & 34,2 & 33,7 & 32,0 & 36,6 & 35,0 & 31,2 & $\because$ & - \\
\hline DAP DA ARVORE MATRIZ ( CM ) & 28,4 & 28,9 & 27,8 & 30,5 & 31,2 & 34,0 & 33,2 & 29,1 & - & - \\
\hline VOOLUME DA ARVORE MATRIZ (STCG) & 0,7153 & 0,7707 & 0,8332 & 0,9830 & 0,9769 & 1,3144 & 1,2020 & 0,8328 & - & - \\
\hline $\begin{array}{l}\text { INDICE DE SELECÃO - } \\
\text { DENS. BASSICA MEDIA -ÁRVORE MATRIZ }\end{array}$ & $\begin{array}{r}25.650 \\
0,392 \\
\end{array}$ & $\begin{array}{l}25.680 \\
0,485\end{array}$ & $\begin{array}{r}10.804 \\
0,380 \\
\end{array}$ & $\begin{array}{r}24.901 \\
0,407 \\
\end{array}$ & $\begin{array}{l}6.117 \\
0,410\end{array}$ & $\begin{array}{r}20.425 \\
0,429 \\
\end{array}$ & $\begin{array}{r}10.985 \\
0,376\end{array}$ & $\begin{array}{l}6.117 \\
0,478 \\
\end{array}$ & - & - \\
\hline
\end{tabular}


TABELA 10: Balanço hidrico mensal segundo "Thornthwa1te - 1984", para a localidade de Avarë-SP, nos ültimos 10 anos (1973/1983)

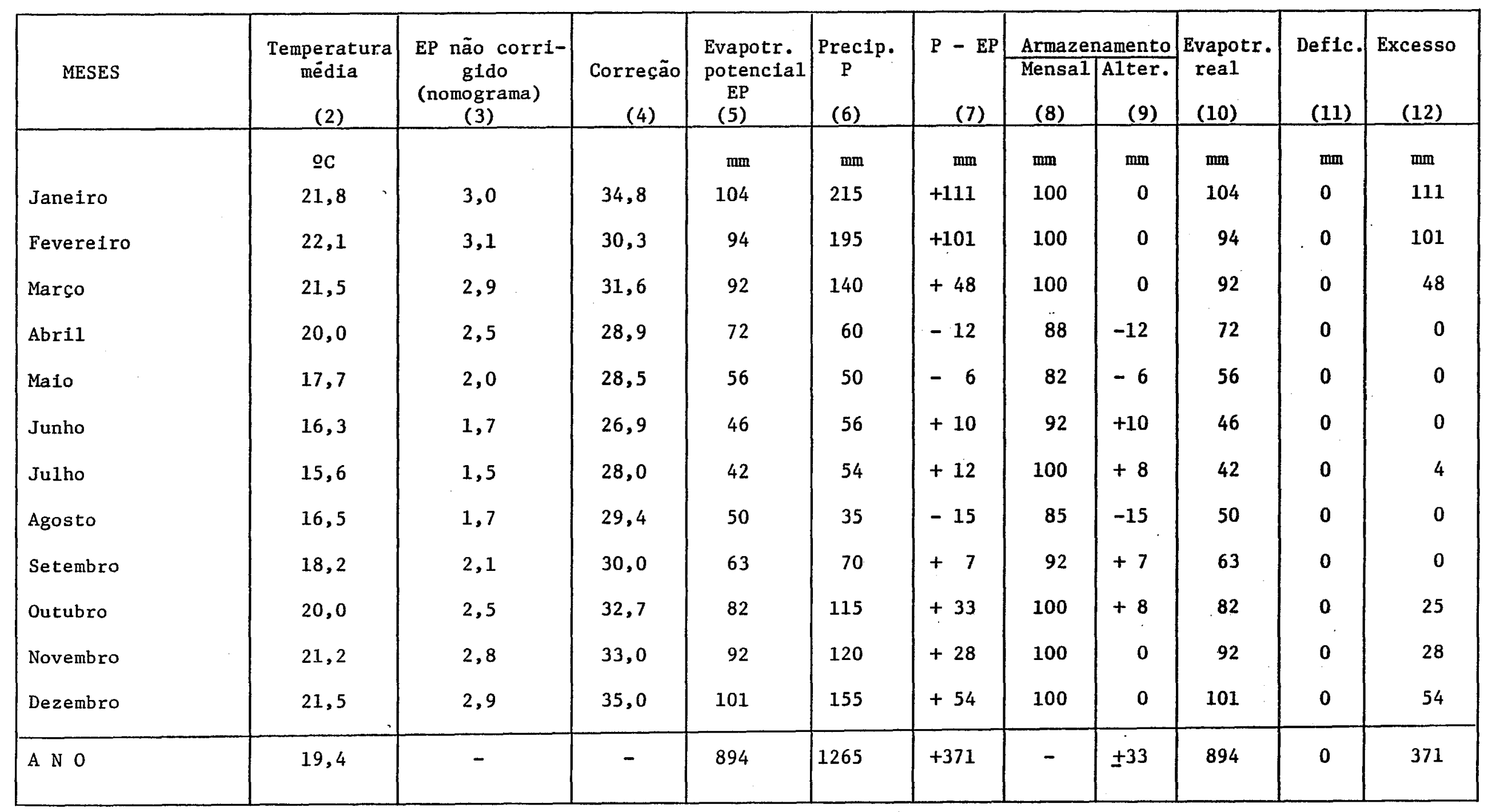


TABELA 11: Anälises laboratoriais fisicas e químicas realizadas nos solos cujas matrizes foram selecionadas.

\begin{tabular}{|c|c|c|c|c|c|c|c|c|c|c|c|c|c|c|c|c|c|c|}
\hline \multirow[b]{2}{*}{$x^{x}$} & \multirow[b]{2}{*}{ matriz } & \multicolumn{2}{|c|}{ Amostras } & \multicolumn{9}{|c|}{$\begin{array}{l}\text { Resultados expressos por volume de terra fina seca ao ar } \\
\qquad \text { mil equivalente por } 100 \mathrm{~cm}^{3} \text { de terra } \\
\end{array}$} & \multicolumn{5}{|c|}{ Resultados em porcentagem } & \multirow{2}{*}{$\begin{array}{l}\text { Classi- } \\
\text { ficação }\end{array}$} \\
\hline & & $\begin{array}{l}\text { qua- } \\
\text { dra }\end{array}$ & $\begin{array}{l}\text { profund. } \\
(\mathrm{cm})\end{array}$ & $\begin{array}{l}\mathrm{pH} \text { em } \\
\mathrm{CaCl}_{2}\end{array}$ & M.o. & $\begin{array}{l}\text { P resina } \\
\text { ugP } / \mathrm{cm}^{3}\end{array}$ & $\mathrm{H}+\mathrm{A} 1+3$ & $\mathrm{~K}+$ & $\mathrm{Ca}^{2}$ & $\mathrm{Mg}^{2}$ & $\mathbf{S}$ & $\operatorname{cTC}$ & $V \%$ & $\begin{array}{l}\text { Areia To } \\
\text { tal mon }\end{array}$ & $\begin{array}{l}\text { Silte } \\
0,05 \\
0,002\end{array}$ & $\begin{array}{l}\text { Argila } \\
<0,002 \\
\end{array}$ & $\begin{array}{l}\text { Densida- } \\
\text { de Red }\end{array}$ & \\
\hline 7 & $G-261$ & 174 & $\begin{array}{r}0-30 \\
30-60 \\
60-100 \\
\end{array}$ & \begin{tabular}{|l|}
4,1 \\
4,2 \\
4,4 \\
\end{tabular} & $\begin{array}{l}1,06 \\
0,94 \\
0,69 \\
\end{array}$ & \begin{tabular}{|l|}
0,54 \\
0,46 \\
0,38 \\
\end{tabular} & $\begin{array}{l}3,1 \\
2,5 \\
3,4 \\
\end{array}$ & $\begin{array}{l}0,03 \\
0,01 \\
0,01 \\
\end{array}$ & $\because$ & $\begin{array}{l}0,09 \\
0,03 \\
0,03 \\
\end{array}$ & $\begin{array}{l}0,12 \\
0,04 \\
0,04 \\
\end{array}$ & $\begin{array}{l}3,22 \\
2,54 \\
3,44 \\
\end{array}$ & $\begin{array}{l}3,72 \\
1,57 \\
1,16 \\
\end{array}$ & $\begin{array}{l}82,9 \\
82,9 \\
76,4 \\
\end{array}$ & $\begin{array}{l}5,7 \\
2,9 \\
8,4 \\
\end{array}$ & $\begin{array}{l}11,4 \\
14,2 \\
15,2 \\
\end{array}$ & $\begin{array}{l}2,12 \\
2,12 \\
2,12 \\
\end{array}$ & LATOSSOLO \\
\hline $\begin{array}{l}1 \\
2\end{array}$ & \begin{tabular}{|l|}
$G-245$ \\
$G-246$
\end{tabular} & 179 & $\begin{array}{c}0-30 \\
30-60 \\
60-100 \\
\end{array}$ & $\begin{array}{l}4,1 \\
4,1 \\
4,2 \\
\end{array}$ & $\begin{array}{l}0,95 \\
0,69 \\
0,52 \\
\end{array}$ & $\begin{array}{l}0,61 \\
0,46 \\
0,38 \\
\end{array}$ & $\begin{array}{l}3,1 \\
2,8 \\
2,5 \\
\end{array}$ & $\begin{array}{l}0,01 \\
0,01 \\
0,04 \\
\end{array}$ & $\therefore$ & $\begin{array}{l}0,01 \\
0,01 \\
0,01 \\
\end{array}$ & $\begin{array}{l}0,02 \\
0,02 \\
0,05 \\
\end{array}$ & $\begin{array}{l}3,12 \\
2,82 \\
2,55 \\
\end{array}$ & $\begin{array}{l}0,64 \\
0,70 \\
1,96 \\
\end{array}$ & $\begin{array}{l}86,1 \\
84,4 \\
83,8 \\
\end{array}$ & $\begin{array}{l}9,3 \\
6,3 \\
8,0 \\
\end{array}$ & $\begin{array}{l}4,6 \\
9,4 \\
8,2 \\
\end{array}$ & $\begin{array}{l}2,25 \\
2,15 \\
2,12 \\
\end{array}$ & $\begin{array}{c}\text { AREIA } \\
\text { QUARTZOSA }\end{array}$ \\
\hline 4 & G-250 & 180 & $\begin{array}{c}0-30 \\
30-60 \\
60-100 \\
\end{array}$ & $\begin{array}{l}4,0 \\
4,2 \\
4,1 \\
\end{array}$ & $\begin{array}{l}1,04 \\
0,64 \\
0,51 \\
\end{array}$ & $\begin{array}{l}0,54 \\
0,61 \\
0,38 \\
\end{array}$ & $\begin{array}{l}3,8 \\
2,8 \\
2,2 \\
\end{array}$ & $\begin{array}{l}0,02 \\
0,01 \\
0,01 \\
\end{array}$ & . & $\begin{array}{l}0,03 \\
0,01 \\
0 \\
\end{array}$ & $\begin{array}{l}0,05 \\
0,02 \\
0,01 \\
\end{array}$ & $\begin{array}{l}3,85 \\
2,82 \\
2,21 \\
\end{array}$ & $\begin{array}{l}1,29 \\
0,70 \\
0,45 \\
\end{array}$ & $\begin{array}{l}91,7 \\
87,6 \\
84,8 \\
\end{array}$ & $\begin{array}{l}3,5 \\
4,6 \\
7,4 \\
\end{array}$ & $\begin{array}{l}4,8 \\
5,8 \\
7,8 \\
\end{array}$ & $\begin{array}{l}2,12 \\
2,05 \\
2,07 \\
\end{array}$ & $\begin{array}{c}\text { AREIA } \\
\text { QUARTZOSA }\end{array}$ \\
\hline 5 & $\begin{array}{l}G-251 \\
G-256 \\
\end{array}$ & 182 & $\begin{array}{c}0-30 \\
30-60 \\
60-100 \\
\end{array}$ & $\begin{array}{l}4,0 \\
4,1 \\
4,1 \\
\end{array}$ & $\begin{array}{l}0,94 \\
0,68 \\
0,49 \\
\end{array}$ & $\begin{array}{l}0,77 \\
0,61 \\
0,46 \\
\end{array}$ & $\begin{array}{l}3,8 \\
3,1 \\
2,5 \\
\end{array}$ & $\begin{array}{l}0,02 \\
0,01 \\
0,01 \\
\end{array}$ & : & $\begin{array}{l}0,03 \\
0,01 \\
0,01 \\
\end{array}$ & $\begin{array}{l}0,05 \\
0,02 \\
0,02 \\
\end{array}$ & $\begin{array}{l}3,85 \\
3,12 \\
2,52 \\
\end{array}$ & $\begin{array}{l}1,29 \\
0,64 \\
0,79 \\
\end{array}$ & $\begin{array}{l}83,9 \\
81,8 \\
79,3 \\
\end{array}$ & $\begin{array}{l}8,5 \\
8,6 \\
6,9 \\
\end{array}$ & $\begin{array}{r}7,6 \\
9,6 \\
13,8 \\
\end{array}$ & $\begin{array}{l}2,12 \\
2,15 \\
2,12 \\
\end{array}$ & $\begin{array}{c}\text { AREIA } \\
\text { QUARTZOSA }\end{array}$ \\
\hline 6 & $G-258$ & 183 & $\begin{array}{c}0-30 \\
30-60 \\
60-100 \\
\end{array}$ & $\begin{array}{l}4,0 \\
4,1 \\
4,2 \\
\end{array}$ & $\begin{array}{l}0,94 \\
0,64 \\
0,52 \\
\end{array}$ & $\begin{array}{l}0,61 \\
0,46 \\
0,38 \\
\end{array}$ & $\begin{array}{l}3,8 \\
3,1 \\
2,8 \\
\end{array}$ & $\begin{array}{l}0,02 \\
0,01 \\
0,01 \\
\end{array}$ & $\begin{array}{l}0,09 \\
0,09 \\
\end{array}$ & $\begin{array}{l}0,03 \\
0,05 \\
0,03 \\
\end{array}$ & $\begin{array}{l}0,05 \\
0,15 \\
0,13 \\
\end{array}$ & $\begin{array}{l}3,85 \\
3,25 \\
2,93 \\
\end{array}$ & $\begin{array}{l}1,29 \\
4,61 \\
4,43 \\
\end{array}$ & $\begin{array}{l}86,9 \\
79,1 \\
82,9 \\
\end{array}$ & $\begin{array}{r}5,5 \\
12,3 \\
7,3 \\
\end{array}$ & $\begin{array}{l}7,6 \\
8,6 \\
9,8 \\
\end{array}$ & $\begin{array}{l}2,15 \\
2,12 \\
2,15 \\
\end{array}$ & $\begin{array}{c}\text { AREIA } \\
\text { QUARTZOSA }\end{array}$ \\
\hline 16 & $\begin{array}{c}\text { SEM. } \\
\text { COMER } \\
\end{array}$ & 231 & $\begin{array}{c}0-30 \\
30-60 \\
60-100 \\
\end{array}$ & $\begin{array}{l}4,0 \\
4,1 \\
4,2 \\
\end{array}$ & $\begin{array}{l}1,02 \\
0,70 \\
0,52 \\
\end{array}$ & $\begin{array}{l}0,61 \\
0,23 \\
0,23 \\
\end{array}$ & $\begin{array}{l}2,2 \\
3,1 \\
2,5 \\
\end{array}$ & $\begin{array}{l}0,02 \\
0,03 \\
0,01 \\
\end{array}$ & 0,09 & $\begin{array}{l}0,03 \\
0,03 \\
0,07 \\
\end{array}$ & $\begin{array}{l}0,05 \\
0,06 \\
0,17 \\
\end{array}$ & $\begin{array}{l}2,25 \\
3,16 \\
2,67 \\
\end{array}$ & $\begin{array}{l}2,22 \\
1,89 \\
6,35 \\
\end{array}$ & $\begin{array}{l}86,1 \\
81,0 \\
81,0 \\
\end{array}$ & $\begin{array}{r}13,8 \\
3,6 \\
6,0 \\
\end{array}$ & $\begin{array}{r}5,8 \\
15,4 \\
13,0 \\
\end{array}$ & $\begin{array}{l}2,12 \\
2,10 \\
2,12 \\
\end{array}$ & $\begin{array}{c}\text { AREIA } \\
\text { QUARTZOSA }\end{array}$ \\
\hline 3 & $\mid G-269$ & 260 & $\begin{array}{c}0-30 \\
30-60 \\
60-100\end{array}$ & $\begin{array}{l}4,2 \\
4,3 \\
4,3 \\
\end{array}$ & $\begin{array}{l}1,34 \\
1,11 \\
0,93\end{array}$ & $\begin{array}{l}0,38 \\
0,30 \\
0,23 \\
\end{array}$ & $\begin{array}{l}4,7 \\
4,7 \\
3,8 \\
\end{array}$ & $\begin{array}{l}0,02 \\
0,02 \\
0,04 \\
\end{array}$ & $\begin{array}{l}0,09 \\
0,09\end{array}$ & $\begin{array}{l}0,15 \\
0,05 \\
0,03 \\
\end{array}$ & $\begin{array}{l}0,26 \\
0,16 \\
0,07 \\
\end{array}$ & $\begin{array}{l}4,96 \\
4,86 \\
3,87 \\
\end{array}$ & $\begin{array}{l}5,24 \\
3,29 \\
1,80 \\
\end{array}$ & $\begin{array}{l}73,4 \\
61,0 \\
61,0 \\
\end{array}$ & $\begin{array}{r}7,6 \\
14,0 \\
13,6 \\
\end{array}$ & $\begin{array}{l}19,0 \\
85,0 \\
85,4 \\
\end{array}$ & $\begin{array}{l}2,17 \\
2,15 \\
2,15 \\
\end{array}$ & LATOSSOLO \\
\hline
\end{tabular}

FONTE: Laboratōrio ICASA - CAMPINAS - SP 
TABELA 12: Caracterização físico-química do solo Podzölico Vermelho Escuro - Faz. Rio Claro.

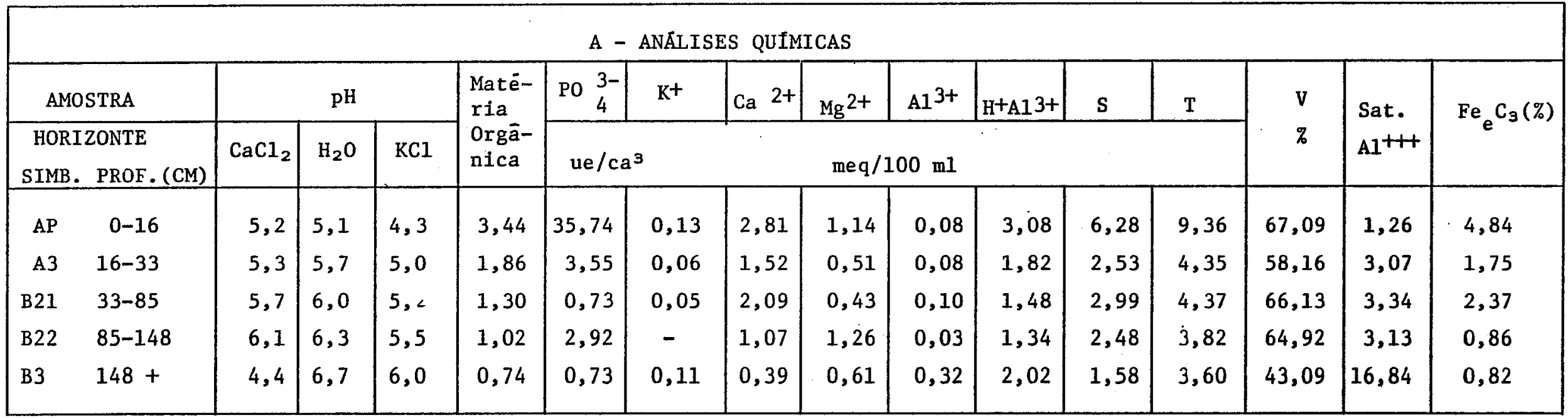

B - ANÁLISES FISICAS

\begin{tabular}{|c|c|c|c|c|c|c|c|c|c|c|c|}
\hline \multirow{3}{*}{\multicolumn{2}{|c|}{\begin{tabular}{|c|} 
AMOSTRA NO \\
HORIZONTE \\
SIMB. PROF. (CM)
\end{tabular}}} & \multicolumn{9}{|c|}{ Anālise Mecānica $(a \Lambda)(\%)$, Pipeta, $\mathrm{NaOH}$ IN } & \multirow{3}{*}{$\begin{array}{c}\text { Grau } \\
\text { F1oc } \\
\%\end{array}$} \\
\hline & & \multirow{2}{*}{$\begin{array}{c}\text { areia muito } \\
\text { grossa }\end{array}$} & \multirow[t]{2}{*}{ areia grossa } & \multirow[t]{2}{*}{ areia mëdıa } & \multirow[t]{2}{*}{ areia fina } & \multirow{2}{*}{$\begin{array}{c}\text { areia muito } \\
\text { fina }\end{array}$} & \multirow[t]{2}{*}{ areia } & \multirow[t]{2}{*}{ limo } & \multicolumn{2}{|c|}{ Argila } & \\
\hline & & & & & & & & & 0,002 & em água & \\
\hline $\mathrm{AP}$ & $0-16$ & - & 2,0 & 21,0 & 32,5 & 6,2 & 61,7 & 18,5 & 19,8 & 14,4 & 27 \\
\hline A3 & $16-33$ & - & 1,7 & 20,7 & 35,2 & 7,0 & 64,6 & 13,9 & 21,5 & 16,4 & 24 \\
\hline B21 & $33-85$ & - & 1,7 & 17,8 & 33,0 & 6,7 & 59,2 & 12,6 & 26,2 & 21,9 & 22 \\
\hline B22 & $85-148$ & - & 1,4 & 17,0 & 32,1 & 6,1 & 56,6 & 9,6 & 33,8 & 4,8 & 86 \\
\hline B3 & +148 & - & 1,8 & 19,1 & 6,5 & 6,5 & 60,1 & 8,7 & 31,2 & 2,7 & 91 \\
\hline
\end{tabular}

FONTE: Laboratörio ICASA - CAMPINAS - SP 
TABELA 13: Caracterização físico química do solo Arela Quartzosa - Faz. Piracema.

\begin{tabular}{|c|c|c|c|c|c|c|c|c|c|c|c|c|c|c|c|c|}
\hline \multicolumn{17}{|c|}{ A - ANALISES QUIMICAS } \\
\hline \multicolumn{2}{|c|}{ AMOSTRA } & \multicolumn{3}{|c|}{$\mathrm{pH}$} & \multirow{2}{*}{$\mid \begin{array}{c}\text { Matēria } \\
\text { Orgā- } \\
\text { nica } \\
\%\end{array}$} & $\mathrm{PO}_{4}^{3-}$ & $\mathrm{K}^{+}$ & $\mathrm{Ca}^{2+}$ & $\mathrm{Mg}^{2+}$ & $\mathrm{Al}^{3+}$ & $\mathrm{H}^{+}+\mathrm{Al}^{3+}$ & $\mathbf{s}$ & $\mathbf{T}$ & \multirow[t]{2}{*}{ V } & \multirow{2}{*}{$\begin{array}{c}\text { Sat. } \\
\mathrm{Al}^{++}+\end{array}$} & \multirow[t]{2}{*}{$\mathrm{Fe}^{\mathrm{e}_{3}(\%)}$} \\
\hline $\begin{array}{l}\text { HOF } \\
\text { SIN }\end{array}$ & $\begin{array}{l}\text { ZONTE } \\
\text {.PROF : (CM) }\end{array}$ & $\mathrm{CaCl}_{2}$ & $\mathrm{H}_{2} \mathrm{O}$ & $\mathrm{KCl}$ & & \multicolumn{8}{|c|}{$\mathrm{ue} / \mathrm{cm}^{3} \quad \mathrm{meq} / 100 \mathrm{ml}$} & & & \\
\hline AP & $0-17$ & 4,0 & 5,5 & 4,5 & 1,40 & 0,73 & - & - & 0,02 & 0,66 & 2,02 & 0,15 & 2,15 & 6,05 & 63,54 & 0,82 \\
\hline A3 & $17-42$ & 4,1 & 4,9 & 4,2 & 1,02 & 0,73 & - & - & 0,02 & 0,67 & 1,82 & 0,12 & 1,96 & 6,19 & 84,81 & 0,82 \\
\hline $\mathrm{Cl}$ & $42-128$ & 4,2 & 5,0 & 4,3 & 1,02 & 0,73 & - & - & 0,01 & 0,51 & 1,48 & 0,06 & 1,54 & 3,90 & 89,47 & 0,93 \\
\hline $\mathrm{C} 2$ & $128-160^{+}$ & 4,2 & 4,5 & 4,4 & 0,84 & 0,36 & - & - & 0,02 & 0,50 & 1,48 & 0,08 & 1,56 & 5,13 & 86,21 & 1,03 \\
\hline
\end{tabular}

B - ANÅLISES FISICAS

\begin{tabular}{|c|c|c|c|c|c|c|c|c|c|c|c|}
\hline \multicolumn{2}{|c|}{ AMOSTRA NO } & \multicolumn{9}{|c|}{ Anālise Mecānica ( ) (\%), Pipeta, NaOH IN } & \multirow{2}{*}{$\begin{array}{c}\text { Grau } \\
\text { Floc } \\
\% \\
\end{array}$} \\
\hline \multicolumn{2}{|c|}{ SIMB. PROF: (CM) } & $\begin{array}{c}\text { areia muito } \\
\text { grossa }\end{array}$ & areia grossa & arela média & areia fina & $\begin{array}{c}\text { areia muito } \\
\text { fina }\end{array}$ & areia & limo & \multicolumn{2}{|c|}{ argila } & \\
\hline $\mathrm{AP}$ & $0-17$ & - & 1,3 & 32,9 & 53,8 & 4,1 & 92,1 & 1,9 & 6,0 & 4,8 & 20 \\
\hline A3 & $17-42$ & - & 1,6 & 32,9 & 49,7 & 4,6 & 88,8 & 1,8 & 9,4 & $3 ; 3$ & 65 \\
\hline $\mathrm{C} 1$ & $42-128$ & - & 1,2 & 29,3 & 50,8 & 6,1 & 87,4 & 2,1 & 10,5 & 7,6 & 28 \\
\hline $\mathrm{C} 2$ & $128-140^{+}$ & - & 1,3 & 28,0 & 45,8 & 7,8 & 82,9 & 3,3 & 13,8 & 6,7 & 51 \\
\hline
\end{tabular}

FONTE: Laboratōrio ICASA - CAMPINAS - SP 